University of Massachusetts Amherst

ScholarWorks@UMass Amherst

2018

\title{
How Do Nascent Social Entrepreneurs Respond to Rewards? A Field Experiment on Motivations in a Grant Competition
}

Ina Ganguli

University of Massachusetts Amherst and Stockholm School of Economics (SITE)

Marieke Huysentruyt

HEC Paris and Stockholm School of Economics (SITE)

Chloé Le Coq

Stockholm School of Economics (SITE)

Follow this and additional works at: https://scholarworks.umass.edu/econ_workingpaper

Part of the Economics Commons

\section{Recommended Citation}

Ganguli, Ina; Huysentruyt, Marieke; and Le Coq, Chloé, "How Do Nascent Social Entrepreneurs Respond to Rewards? A Field Experiment on Motivations in a Grant Competition" (2018). UMass Amherst Economics Working Papers. 258.

https://doi.org/10.7275/13490553

This Article is brought to you for free and open access by the Economics at ScholarWorks@UMass Amherst. It has been accepted for inclusion in Economics Department Working Paper Series by an authorized administrator of ScholarWorks@UMass Amherst. For more information, please contact scholarworks@library.umass.edu. 


\title{
How Do Nascent Social Entrepreneurs Respond to Rewards? A Field Experiment on Motivations in a Grant Competition
}

\author{
Ina Ganguli ${ }^{1,4}$, Marieke Huysentruyt ${ }^{2,4}$, and Chloé Le Coq ${ }^{3,4}$ \\ November 2020 \\ ${ }^{1}$ University of Massachusetts Amherst \\ ${ }^{2}$ HEC Paris \\ ${ }^{3}$ University of Paris 2 Panthéon-Assas (CRED) \\ ${ }^{4}$ Stockholm School of Economics (SITE)
}

\begin{abstract}
$\underline{\text { Abstract }}$
We conducted a field experiment to identify the causal effect of extrinsic reward cues on the sorting and performance of nascent social entrepreneurs. The experiment, carried out with one of the United Kingdom's largest support agencies for social entrepreneurs, encouraged 431 nascent social entrepreneurs to submit a full application for a grant competition that provides cash and in-kind mentoring through a one-time mailing sent by the agency. The applicants were randomly assigned to one of three groups: one group received a standard mailing that emphasized the intrinsic incentives of the program, or the opportunity to do good (Social treatment), and the other two groups received a mailing that instead emphasized the extrinsic incentives - either the financial reward (Cash treatment) or the in-kind reward (Support treatment). Our results show that an emphasis on extrinsic incentives has a causal impact on sorting into the applicant pool: the extrinsic reward cues led fewer candidates to apply and "crowded out" the more prosocial candidates while "crowding in" the more money-oriented ones. The extrinsic reward cues also increased application effort, which led these candidates to be more successful in receiving the grant. Yet, the selection resulting from the extrinsic incentive cues led to worse performance at the end of the one-year grant period. Our results highlight the critical role of intrinsic motives in the selection and performance of social enterprises and suggest that using extrinsic incentives to promote the development of successful social enterprises may backfire in the longer run. (JEL: C93, J24, L31, 035)
\end{abstract}

Keywords: social entrepreneurship, field experiment, incentive, intrinsic motivation, grants

*The authors express gratitude to our partner organization for implementing the field experiment and for providing us with the relevant data. We gratefully acknowledge support from the European Union's Seventh Framework Program for research, technological development and demonstration under grant agreement 613500 (SEFORÏS project). We appreciate assistance from Bogdan Prokopovych and Edvard Von Sydow. We thank participants of SEFORÏS Consortium meetings, the SITE network conference, SnO Research Day at HEC Paris, the IGL Research Meeting at Harvard Business School, the policy seminar at OECD, the Stockholm Behavioral workshop, Nonprofits, Government, and Organizations Research Network Workshop at Stockholm School of Economics, and seminars of the World Bank, Inter-American Development Bank, Riga SSE, Cergy University, Bologna University, Singapore Management University and Mitali Banerjee, Mark Bernard, Marieke Bos, Emma von Essen, Patrick Gaulé, Johanna Mair, John Mawdsley, Topi Miettinen, James Phipps, Tomasz Obloj, William Ocasio, and Ute Stephan for useful comments and feedback. 


\section{Introduction}

Today's major societal challenges - such as climate change, migration and inequality - urgently call for new ideas and approaches that can create both economic growth and social value. Recent years have seen a surge of support programs targeted specifically at nascent social entrepreneurs, new actors on the innovation scene, widely thought to be invaluable for bringing forth and inspiring such ideas (OECD 2011).

To attract high-quality candidates, these support programs typically not only appeal to candidates' intrinsic motivation to make a real, positive difference in society, but also offer participants extrinsic rewards, ${ }^{2}$ mostly cash and in-kind support. They thus seek to tap multiple motives - that is, extrinsic (financial or in-kind) and intrinsic (prosocial) motives - for candidates to apply and pursue a social entrepreneurial career, as if these motives are complementary. Yet, it is unclear how these mixed incentives causally impact who applies (the size and composition of the applicant pool), applicant success, and whether selection has a causal impact on subsequent social entrepreneurial success.

This paper presents novel experimental evidence showing that extrinsic reward cues strongly affect which nascent social entrepreneurs apply for support, and hence also the type of project submitted. The reward cues also impact application effort and subsequent success in receiving support. A key and novel contribution of our paper is that we are able to characterize the causal effect of extrinsic reward cues on sorting in full - both who opts in and who opts out of the competitive grant-seeking process. Furthermore, leveraging our experimental design and longer-run outcome data on the grantees, we are also able to assess the causal impacts of selection on social entrepreneurial outcomes one year later.

\footnotetext{
${ }^{1}$ Social entrepreneurs combine societal goals with entrepreneurial spirit. They focus on achieving wide social, environmental or community objectives, through the provision of goods and services in markets, private and public alike (Mair and Marti 2006; Huysentruyt et al. 2016). They are primarily intent on exploiting opportunities for social change and improvement, rather than traditional profit maximization (Zahra et al. 2009). A nascent social entrepreneur is defined as someone who is involved in the start-up process of a social enterprise but has not paid salaries, wages, or any other payment to the owners for more than three months (Bosma et al. 2016). Nascent social entrepreneurs typically have a plan but have yet to experience three months of positive operating revenues (Reynolds et al. 2004).

2 "Extrinsic rewards" are traditionally defined as contingent, ex post rewards (Bénabou and Tirole 2003). They can take a monetary and non-monetary form (Frey 1994). Standard economic theory predicts that such rewards affect behavior only by altering the economic costs and benefits of the target activity (Bowles and Polania-Reyes 2012).
} 
To conduct the field experiment, we collaborated with one of the United Kingdom's largest support agencies for nascent social entrepreneurs. The experiment encouraged 431 nascent social entrepreneurs to submit an application for a 12-month grant program, which provides cash and in-kind mentorship ${ }^{3}$ support to social entrepreneurs, through a one-time mailing sent by the support agency via email after entrepreneurs had indicated initial interest in the program. The individuals were randomly assigned to three groups: one group received a standard mailing emphasizing the intrinsic incentives only - the opportunity to do good (Social treatment), and the other two groups received a mailing that emphasized the extrinsic rewards either the financial rewards (Cash treatment) or the in-kind rewards (Support treatment) that the grant program provides. A key feature of our design is that we consider the full pool of potential applicants, as we observe all individuals who had successfully completed an Expression of Interest (EOI) form, which is a first required screening. Equally as important to our design is that we can isolate the effects of selection since our experiment varies just the salience of extrinsic rewards at the application stage. Application requirements are kept equal across groups and once admitted into the grant program, all grantees actually receive the same rewards. We thus sever the link between our treatments and incentives once in the grant program and so are able to isolate the effects of selection on subsequent performance of nascent social enterprises.

In our analysis, we combine several data sources and measurement methods. First, we exploit the text responses contained in the EOI to develop linguistic measures of the candidates' orientations or proclivities (such as, prosocial or money orientation) before treatment. These documents also contain valuable information about the candidates' prior professional experiences and ex ante needs. Second, using the full written application forms combined with detailed information about the rejected applications, we are able to compare across treatments application performance, while holding constant measures of ex ante applicant quality and needs. Further, we use the detailed application materials and end-of-grant survey, both

\footnotetext{
${ }^{3}$ Mentorship is traditionally defined as the interpersonal exchange between an experienced, knowledgeable person (i.e., the mentor) who provides advice, counsel, feedback and support related to career and personal development for a less experienced person (Kram 1985; Noe et al. 2002). Throughout the paper we also refer to this as support.
} 
administered by our partner organization, to examine relevant measures of the start-up venture type (such as the target beneficiary) and social entrepreneurial performance outcomes at the end of the one-year program. Combined, these data allow us to determine whether nascent social entrepreneurs' motives impact their venture's early success.

We have three main findings. First, the extrinsic reward cues impacted sorting into the grant competition. We find evidence of a crowding out of prosocial candidates following the Cash treatment. In the Cash treatment group, not only did fewer candidates apply, but applicants were significantly less prosocial and more money-oriented compared to those in the Social and Support treatment groups. Consistent with this finding, applicants were also less likely to mention that disadvantaged groups would benefit from their future social enterprise and more likely to report social impact as a challenge for their venture. The Support treatment did not crowd out prosocial candidates, although it did lead to somewhat, but not significantly so, fewer candidates applying. We find no find evidence of sorting based on individual ability, needs or prior professional experience. Rather, sorting, especially in response to the monetary extrinsic reward, seems to arise due to differences in individual pro-social and monetary inclinations.

Second, the extrinsic reward cues also impacted who got selected into the grant program. Those submitting a full application following either of the two extrinsic reward cues were significantly more likely to win the grant. This is likely due to greater application effort spent in response to these cues. Applicants in the Cash group in particular were less likely to be rejected for submitting an incomplete application, requested a lower amount of money, even though their financial needs were the same, and were more likely to engage in self-promotion. Applicants in the Support treatment group were more likely to submit their application on time, although the evidence on greater application effort spent is weak.

Third, the successful applicants following both the extrinsic monetary and in-kind reward cues performed effectively worse at the end of the one-year grant period. They spent on average 8 hours less working on their venture each week; created significantly fewer job opportunities in the prior 12 months; and fewer people directly benefited from their venture over the prior 12 months. This performance difference cannot be explained by an incentive effect once selected into the grant program, since all grantees 
received the same rewards, intrinsic and extrinsic alike. It is more likely the result of selection at the application stage, both in terms of: (1) who entered the applicant pool, and (2) who became a grantee. Our results suggest that the crowding out of prosocial applicants contributed to worse performance outcomes. They also suggest that self-promoting behavior (Cash treatment) or being on time (Support treatment) at the application stage do not lead to longer-term social entrepreneurial success. Our data, however, do not allow us to pinpoint the dimension along which Support may have produced differential selection. Taken together, our results highlight the critical role of intrinsic motives for the performance of nascent social entrepreneurial enterprises and show that using extrinsic incentives to promote the development of nascent social entrepreneurship may backfire in the longer run.

By demonstrating that subtle incentive cues can affect who participates in a competitive grantseeking setting and the effort they put forth when applying, these results have important implications for both the effectiveness of entrepreneurship support programs and entrepreneurship policy. Program frames are often chosen inadvertently, even in a setting where intrinsic motivation is known to play an important role, as if they matter little. If our results generalize to entrepreneurship support program take-up and even more generally to employee program take-up, then the framing of messaging for such programs should be carefully considered. Further, given the proliferation of social enterprise support programs, it is important to gain insight into the types of individuals these programs benefit most. To develop successful new social enterprises, our results suggest that these programs may be effective by appealing to and investing in individuals who are more intrinsically-motivated.

This paper contributes to several strands of literature. First, our paper ties into the literature on the crowding out effect of extrinsic rewards. In 1972, Richard Titmuss argued against monetary compensation for blood donors because of the potential crowding out effect of such a reward, which could lower donations. Recent experimental research has studied the effects of extrinsic (monetary) rewards on effort choice, mostly in prosocial settings like blood donations (Lacetera et al. 2014) or charitable donations (e.g., Gneezy and Rustichini 2000; Ariely et al. 2009; for a review article see Gneezy et al. 2011 and Bowles and 
Polania-Reyes 2012). ${ }^{4}$ Most experimental designs, however, do not allow for sorting, and thus largely sideline the selection effect (Lazear et al. 2012). Our data allow us to directly evaluate and contrast both those who opted in (crowding-in) and those who opted out (crowding-out) of the grant competition, and hence advance a more complete characterization of treatment effects compared to closely related work. ${ }^{5}$ Our setting provides a unique opportunity to study whether the extrinsic incentive types (financial versus in-kind rewards) matter, especially as the monetary value of the two reward types is roughly equivalent ( $£ 5,000$ in cash or $£ 5,000$ worth of mentoring support).

In a paper closely related to ours, Ashraf, Bandiera, Davenport and Lee (2020) ask whether job candidates attracted by career incentives have traits that differ from those attracted by 'doing good' and whether this selection affects subsequent performance. Unlike our experimental design, however, their setup only provides data on who applied (opted in) but not on who did not apply (opted out), and thus they are unable to address the question of crowding out of potential applicants. Our paper is, to our knowledge, the first to show that extrinsic reward cues can crowd in the more money-oriented and crowd out the more pro-socially-oriented nascent social entrepreneurs, which may in turn adversely impact the early-stage performance of their ventures. ${ }^{6}$ In a similar vein, Deserrano (2019) finds that financial incentives can crowd out the most pro-socially motivated applicants for a job vacancy at an NGO, and lead to lower performance of the new recruits. Together with Desarrano (2019), our findings both extend the boundary of the crowding

\footnotetext{
${ }^{4}$ The experimental literature has found that extrinsic monetary rewards may reduce intrinsic motivation, leading to a reduction in effort, particularly in settings where intrinsic motivation is very salient (Hossain and Li 2014), when rewards are perceived to be too low (Gneezy and Rustichini 2000), and effort (or contributions) are publicly observable (Ariely et al. 2009), though this effect may well vary across individuals. Lacetera et al. (2014) show using a field experiment that they conducted together with the American Red Cross that experienced, former blood donors increased blood donations following extrinsic rewards possibly because they were less concerned with rewards undermining their self-image or intrinsic motivations. The term 'crowding out effect' has previously also been used to denote the reduction in individual spending on a public good, like private donations to charities, in response to an increase in government spending, like government grants to charities (e.g., Andreoni and Payne 2011; List 2011).

${ }^{5}$ Most RCTs do not collect detailed data on those who do not respond to a particular treatment. A key feature of our design is that the intervention takes place between the two application stages (the "Expression of Interest" and the subsequent "Full Application" stage), allowing us to check that our randomization has really worked: that is, that the incentive cues have effectively crowded in and out different candidates based on their individual orientation or proclivity (measured ex ante).

${ }^{6}$ This result is in line with the labor market literature stressing that "mission-oriented" workers exert more effort (e.g. Besley and Ghatak 2005). Also, Deci et al. (1999) provide an extensive overview of the experimental literature looking at the effects of extrinsic rewards on intrinsic motivation.
} 
out effect to settings where extrinsic rewards are nontrivial (Gneezy and Rustichini 2000) and intrinsic motives are highly salient (Hossain and Li 2014), and emphasize the heterogeneity of this effect in our study populations. We demonstrate that monetary incentive cues had a strong motivating effect at application stage, but only for money-oriented candidates. Further, while both the monetary and nonmonetary rewards had a significant impact on applicants' incentives to spend effort to apply, the in-kind support cue did not crowd out prosocial candidates. Similarly, Grillos (2017) shows that in-kind incentives designed to encourage sustainable land management did not crowd out prosocial motivation, and even led people to prioritize environmental values more. Finally, and more generally, within the large body of research on incentives, selection and performance (with seminal contributions by Laffont and Maskin (1982); and the classic Roy model (1951)) ${ }^{7}$, identifying the causal effects of selection on outcomes has been notoriously difficult (e.g. Manski (1993) and the recent literature review on extrinsic and intrinsic motives and work performance by Cassar and Meier (2018)). We address this challenge by exploiting our experimental design to exogenously vary the sorting of candidates and their application performance, and then by exploiting longer-run outcomes data to isolate the effects of any selection on subsequent performance measures.

A second contribution is that our paper advances the emerging literature using experiments to better understand how institutional and organizational designs shape innovation outcomes (see for an overview Boudreau and Lakhani 2016 and Brüggeman and Bizer 2016). ${ }^{8}$ Prior research has experimentally studied the effects of subsidies and other public support programs on innovativeness (e.g., Brüggeman and Proeger 2017), and analyzed creativity under different payment regimes (e.g., Ederer and Manso 2013). We shift focus in two important ways: First, we consider measures designed to stimulate social or sustainable

\footnotetext{
${ }^{7}$ In the field of economics, the question of how extrinsic and intrinsic motives interact has received relatively little attention presumably because economists have routinely assumed either that intrinsic motives are absent, or if they recognized motives other than self-interest, assumed (for the most part unwittingly) that the two sets of motives are separable (Bowles 2016).

8 There also exists a related experimental literature on entrepreneurship that explores the relation between entrepreneurship training programs and entrepreneurial outcomes (e.g., de Mel et al. 2014). To our knowledge, these studies do not look specifically at the sorting effects induced by changes in a program (or its presentation), nor at the potential crowding out effect of explicit monetary transfers tied to program participation.
} 
business innovations, innovations that are both economic and social in their means and ends. Given the hybrid nature of the innovations pursued by social entrepreneurs, it is a priori unclear how extrinsic incentives might affect sorting and performance in our setting. To date, there has been very little experimental work on social innovation, despite the recent, rapid surge of policy-making interest. ${ }^{9}$ Second, thanks to our unique design, we are able to gauge the relative importance of intrinsic and extrinsic motivation to socially or sustainably innovate. A recent study by Guzman, Oh and Sen (2020) similarly examines the effect of social or money frames on selection of innovative entrepreneurs into a competition, but does not differentiate between the channels or examine the longer-run entrepreneurial outcomes.

Third, our paper also contributes to the emerging literature on nascent entrepreneurship. Nascent social entrepreneurs, in particular, have received little scholarly attention so far, in part because they are especially difficult to find. ${ }^{10}$ There exist valuable empirical studies on the motives of nascent social entrepreneurs, which are mainly based on small samples (e.g. Germak and Robinson 2014; Renko 2013). However, these prior studies rely on self-reported motives, which relative to our own behavioral measures, are more susceptible to survey bias. Further, we complement (and cross-validate) our behavioral measure of motives with linguistic indicators of self-, other-, social process- and money-orientation (similar to the approach in Chandra (2016)), which we derive by applying two linguistic software programs (LIWC and DICTION) on the applicants' rich text responses in their EOI statements.

Finally, our experimental manipulation is motivated by a large and robust literature in the social sciences on the framing effect. That is, the fact that individual choices are remarkably susceptible to the way information is presented. Bless and Schwarz (1998) and Wänke et al. (1997), among others, argue that subtle content cues can affect the ease with which goals (or motives) come to mind, even shape what we

\footnotetext{
${ }^{9}$ von Essen et al. (Forthcoming) study joint exploration for the public good, and thereby deploy a novel experimental paradigm to analyze individual's sequential exploration decisions, when information and pay-off externalities coexist.

${ }^{10}$ Nascent social entrepreneurs represent a 'hidden' population (Heckathorn 1997). (i) They are rare (seldom occurring and geographically dispersed); (ii) there exists no administrative database that can be used as a sampling frame; and (iii) they are difficult to identify (e.g., because they do not always self-identify as a nascent social entrepreneur and public acknowledgment is erratic and subjective).
} 
value, and alter subsequent behavior. While this earlier literature is mostly based on laboratory experiments, our study considers a real-life setting. Our paper is among the few studies (Dal Bó et al. 2013, Ashraf et al. 2020, Desaranno 2019, Guzman et al. 2020) that demonstrate empirically the power of minor content cues in the domain of important career-related decisions. Other field experiments have similarly evidenced strong effects of seemingly minor content cues on behavior, such as in the realms of consumer finance (Choi et al. 2017), charity giving (Kessler and Milkman 2018), organizational public goods (Blasco et al. 2019), academic science (Ganguli et al. 2017) and crowd science (Lyons and Zhang 2019). Further, and of special relevance to our understanding of labor market outcomes, our findings reveal that such minor cues may trigger greater self-promoting behavior or more strategic writing of the application to please the reviewers, which, as found elsewhere (e.g. Exley and Kessler 2019), correlates with worse actual performance outcomes.

The remainder of this paper proceeds as follows. Section 2 details the setting and experimental design. Section 3 outlines our main behavioral hypotheses. Section 4 describes the experiment and the data. Section 5 presents our empirical results, and Section 6 concludes. 


\section{Setting and Experimental Design}

\subsection{Setting}

Our partner organization is one of the United Kingdom's largest support agencies in the field of social entrepreneurship. To date, it has distributed over 12,000 grants and $£ 40$ million to social entrepreneurs across the UK. Grants include not only funding, but also advice through one-to-one support, and access to networks and pro-bono mentors during a 12-month grant period. The structure of their program is similar to some of the most visible support programs targeted at social entrepreneurs across the globe.

The agency has a charitable status, and thus must abide to the non-distribution constraint and fulfill a charitable goal, which is to support the start-up of successful social ventures. The agency selects its grantees through a careful, competitive selection process. The first round of application consists of a short online application form (the EOI) that enquires about the social enterprise and the applicant. Each EOI is reviewed by a committee of several grant managers. Those candidates whose EOI passes the first assessment are then invited via email to proceed to the second round of the application process, which involves completing a full application form that asks the applicant to explain in more detail their venture, past experiences and current needs. They are given a deadline to submit the full application within 30 days. As we describe in detail in the next section, we intervene at this point by including our incentive frames in the email sent to invite candidates to submit a full application.

The committee of grant managers uses a standardized set of criteria to evaluate each full application (e.g. the expected social impact of the venture and the clarity of goals and outputs) and decides on the grant winners. Our experiment was implemented between the first and second round of the application process (see Figure 1 and Figure A1). The typical candidate applying for the grant program is at the start-up stage 
of her venture development, although much work has likely already gone into structuring and operationalizing her social enterprise idea. ${ }^{11}$

Today, approximately $2.3 \%$ of the UK's active population is involved in nascent social entrepreneurial activity or involved in the start-up process of a social enterprise (Bosma et al. 2016). Social enterprise has been high on the UK's national policy agenda for over 15 years now. To illustrate, in 2004, the UK introduced the 'community interest company', one of the first legal forms worldwide specifically for social enterprises. Further, in 2012, Big Society Capital was launched, a $£ 600$ million investment fund with monies coming from dormant bank accounts and specifically earmarked for other intermediary bodies (like the organization we collaborated with in the present study) to give financial or other support to third sector organizations. Public and private interest to promote social entrepreneurship is unlikely to fade in the near future, as social enterprises are widely hailed as essential partners to help build a more inclusive economy, especially in the United Kingdom where our partner operates.

While the specific features of our data and setting allow us to advance our understanding of how reward cues can affect sorting and application performance of nascent social entrepreneurs (i.e. at the time of applying for the grant, the venture did not yet formally exist), we note that these specific features also raise issues of external validity. First, our sample frame coincides with the nascent social entrepreneurs who had already passed a first hurdle (the first round of the application process), rather than nascent social entrepreneurs at large. By voluntarily submitting an EOI, these nascent social entrepreneurs may have already shown special promise and verve. The influence of our incentive frames on candidates' behavior may well have been greater still had the intervention occurred at an earlier stage in the enterprise, thereby reaching a more heterogeneous group of nascent social entrepreneurs more representative of the population at large. Second, despite a very high response rate to the end-of-program survey (close to $70 \%$ ), caution

\footnotetext{
${ }^{11}$ For example, one of the candidates wished to start-up a venture that offers school-based, interactive cooking classes for students and their parents or caregivers that addresses the restrictions to cheap, healthy food. She had already run a successful mini-pilot sponsored by a local supermarket store, but at the time of applying for the grant, had not yet set up a legal entity or secured any sales. Another candidate wished to help reduce re-offending by supporting prisoners and ex-prisoners into further/higher education, accredited training, voluntary work and employment.
} 
must be applied when interpreting the longer-term performance effects of selection. Third, our experiment was not designed specifically to compare the effects of different sized rewards on application outcomes and subsequent social entrepreneurial success. Nevertheless, ex post exploratory analysis of a much smaller pool of large-grant applicants (with cash awards of up to $£ 20,000$ instead of $£ 5,000$ ) who we exposed to the same incentive cues suggests that the incentive cues for this larger award amount group yielded no average effect on effort to apply or selection.

\subsection{Experimental Design}

The experiment was implemented for one year, from January 2015 to January 2016. By July 2017, all grant winners had finished their 12-month program period. Figure 1 illustrates the timing of the application process and our intervention, while Figure A1 illustrates the experimental design in more detail. Both figures elucidate that the goal of our experiment is to estimate the causal impact of the treatments on sorting into the applicant pool (among the EOI submitters) and on effort expended among applicants, followed by the impact of selection at the application stage on performance outcomes 1-year later. Key to our design is that all awardees eventually received the same cash and support, so the impacts we estimate is due to our interventions at the application stage.

EOI submissions were considered on a rolling basis, and we thus regularly received lists from our partner organization with the anonymized EOI submissions, including identification numbers, gender, age and location of potential applicants. Within each EOI list we received, we randomly assigned individuals to one of the three treatment groups. ${ }^{12}$ Treatments were designed to detect whether a subtle incentive cue can shape subsequent application outcomes. While all EOI candidates received the standard email to invite them to submit a full application (mentioning the requested information as well as the timing of the selection

\footnotetext{
${ }^{12}$ To assess whether the primes themselves had an effect, as a manipulation check for 6 months, we introduced a fourth group that received the same email but without any prime at all. The sample includes only the individuals submitting an EOI during those 6 months, so the sample is small, and the estimates are noisy. In line with the behavioral literature on "framing effect", the Prime groups (i.e. Cash, Support and Social treatments) do differ from the No Prime group, suggesting that subtle cues embedded in the emails had an effect.
} 
process), these emails additionally embedded a different incentive cue: either emphasizing the extrinsic rewards (Cash or Support) or repeating the intrinsic rewards (Social) that the grant affords, as is standard in all communication about the grant support program. An example of the full email is provided in Appendix A6. The text of the different treatment cues are as follows:

Social treatment:

"If your application is successful, this award will provide you with the opportunity to make a difference by helping transform communities and tackle the many social challenges we face. We aim to bring people together in a common cause to inspire hope for the future and build people's confidence to act."

Cash treatment:

"If your application is successful, this award will provide you with various resources, notably a cash award of up to £5,000. We provide these financial resources that can help you take the next step in your journey."

Support treatment:

"If your application is successful, this award will provide you with 1-to-1 support with an award manager to help you take the next step in your journey. We work with you to grow your plans and access the help you need."

Thus, each of our treatments stresses only one component of the grant that all awardees receive, either the $£ 5,000$ cash award or the 1-to-1 support, but all grantees receive these benefits. For the 1-to1 support, over the course of the 12-month grant period, the award manager and grantee typically meet up for 10 to 14 hours in total, which at a daily consultancy rate of $£ 350$ to $£ 500$, suggests that the market or monetary value of the 1-to- 1 mentoring is about $£ 5,000$. An advantageous feature of our experimental setting and design is indeed that the cash and in-kind rewards are roughly value-equivalent. Comparing the outcomes between the cash and the mentoring cue treatment therefore allows us to shed new light on the role of the rewards' form (monetary versus in-kind) to application behavior.

We then subsequently measure who submits a full application and who is successful in winning the grant. The committee of grant managers who reviewed the full applications was blinded to the experiment. They applied a standard and commonly known set of evaluation criteria, whereby the expected social 
impact and sustainability of the business model carry the biggest weight in the overall assessment. ${ }^{13} \mathrm{We}$ then measure social entrepreneurial outcomes 1 year later.

Key to our research design is that while we vary the salience of incentives at the application stage, all grantees receive identical support from the agency, i.e. the same amount of funding and mentoring. Thus, we are able to estimate the effects of selection and effort in response to the incentive cues rather than impacts of different incentives induced by the award itself.

\section{Behavioral Hypotheses}

The grant competition we study corresponds to a standard principal-agent framework, where the grant-making agency (the principal) offers rewards to raise the quality of the application, and hence, the future performance of the awarded social enterprise. ${ }^{14} \mathrm{~A}$ candidate (the agent) applies by considering the benefits and the costs of pursuing her nascent social enterprise idea and writing the grant application. Importantly, the cost-benefit analysis conducted by the agent depends on the types of motives she holds to engage in the social entrepreneurial activity (and thus apply for the grant), as well as the type of rewards that the grant making agency promises.

Specific to our context, social entrepreneurs have been found to be on average strongly pro-socially oriented; but also, considerable heterogeneity exists both in terms of the strength of their prosocial inclination and the importance that they attach to this versus other types of motives (Huysentruyt et al.

\footnotetext{
${ }^{13}$ We were not able to access the written evaluations of all applications. However, we were granted access to the rejection reasons for the unsuccessful applicants. Systematic analysis of these rejection reasons reveals that social impact and business model are the two most important evaluation criteria. The prevalence of these two rejection reasons are the same across groups, which suggests that indeed evaluation committees systematically apply these criteria. This is also what the grant making agency clearly communicates on its website. These criteria are known to candidate applicants. Therefore, any differences in application success rates can be safely attributed to the incentive and sorting effects of the reward cues.

${ }^{14}$ According to the agency's selection criteria (as detailed in section 2.2), the application's quality depends on the credibility of the overall business plan as well as the social impact of the future venture. It is implicitly assumed that the quality of the application and the quality of the (future) social venture is correlated. Indeed, receiving rewards is conditioned on being successful in the grant competition (that is, having a project with high quality).
} 
2016; Zahra et al. 2009). ${ }^{15}$ In line with Bénabou and Tirole (2003) and Bowles (2016), it is plausible that candidate applicants are intrinsically motivated to apply for a grant to start up a social enterprise, because of ethical, generous and/or other-regarding pro-social concerns, but also, to varying extent, are extrinsically motivated to do so, motivated by the extrinsic rewards the grant program affords.

While the standard economic literature assumes that the behavioral effect of extrinsic rewards and intrinsic motivation are separable, the effects of each being independent of the levels of the other, the psychology literature (e.g. Deci and Ryan 1985) argues for a more subtle interaction effect (Bowles 2016). Extrinsic monetary and non-monetary rewards alter the expected economic benefits and gains of some targeted activity and stimulate extrinsic motivation but can also undermine intrinsic motivation. Following Frey's (1994) terminology, extrinsic rewards may "crowd out" intrinsic motivation or "crowd in" extrinsic motivation, leading the agent to act accordingly. In our setting, the selection process is two-pronged: It depends on who sorts into the grant competition (who applies) and in turn who gets selected into the grant program (which depends, holding ability and quality constant, on the application effort spent). We next discuss the impact of monetary and in-kind rewards at both stages of the selection process: sorting and application performance.

\subsection{Sorting Into and Out of the Grant Competition}

By making salient the available extrinsic rewards, the grant-making agency is likely to disproportionately appeal to candidates who are more extrinsically motivated. ${ }^{16}$ At the same time, the grantmaking agency may well unintentionally discourage those who are more intrinsically motivated to apply.

\footnotetext{
${ }^{15}$ Representative samples of social entrepreneurs in seven European countries plus China and Russia have been found to attach greater weight to self-transcendence values relative to population representative samples or representative samples of comparable commercial entrepreneurs (Huysentruyt et al. 2016).

${ }^{16}$ An alternative hypothesis is that the extrinsic reward cues appeal more to people who lack funding or mentoring support. On the extensive margin then, provided nascent social entrepreneurs vary in the needs they have, we would expect to find a greater share of candidates with a funding need or mentoring need to apply following, respectively, the money and mentoring reward cues. We test and discuss at length this and other possible competing predictions in our empirical section.
} 
In our setting, extrinsic rewards may well crowd in the more money-oriented candidates, and by undermining prosocial motivation, crowd out the more prosocial candidates.

One plausible mechanism responsible for this sorting effect relates to the (self-) signaling value of applying. Assume that extrinsic rewards enter a candidate's cost-benefit analysis in two distinct ways. First, such explicit rewards alter the expected economic costs and benefits of applying to start up one's own social venture. Second, they also affect the agent's image benefits of applying (Exley 2018, Bénabou and Tirole 2006, Baumeiseter 1998, Bodner and Prelec 2003). The presence of extrinsic rewards can undermine the self-image value of applying for those who are more strongly intrinsically motivated. This specific behavioral mechanism has special relevance for our experimental setting with hybrid organizations that combine social value creation with profit-making or commercial success (Mair and Marti 2006). Therefore, image concerns are likely to play an important role influencing the choice of social entrepreneurs, especially at the beginning of their social entrepreneurial career when the asymmetry of information about candidates' true motives tends to be more pronounced and the adverse selection problem is more severe.

While cash and mentoring both constitute contingent, ex post rewards (Bénabou and Tirole 2003), they are likely to differ in the extent to which they elicit crowding in and crowding out effects. In line with prior work that has studied the role of in-kind transfers versus financial incentives in the context of environmental behavior (Grillos 2017), tax systems (Currie and Gahvari 2008) and the health sector (Lieber and Lockwood 2018), the in-kind nature of the reward may well dampen the magnitude of the crowding effects. Mentoring may even crowd in the more pro-socially oriented candidates, given evidence elsewhere that mentorship is more likely to appeal to more pro-social individuals (Noe, Greenberger and Wang 2002; Turban and Lee 2007). Compared to the cash prize, mentorship is an illiquid asset, less transferable or less easily divestible to tasks other than the social entrepreneurial activity. This mutes the negative effect of the signaling value of applying following the mentoring cue. Finally, precisely because mentoring is less liquid, the mentoring cue may to a lesser extent attract money-oriented candidates, resulting in a weakened crowding-in effect. 
All in all, the net impact of the crowding in and crowding out effects on the number of applicants is a priori ambiguous and will depend on the relative share of candidates who are predominately prosocial versus candidates who are predominantly money-oriented. In our setting and given prior research, we would expect that relatively more applicants are pro-socially oriented, which would imply a lower number of actual applicants. We use the rich text fields of the initial EOI to produce linguistic measures of the candidates' social- and money-orientation (described in detail in Section 4.1). As these measures capture the candidates' orientation prior to our intervention, they allow us to test both the crowding out and crowding in effects. Furthermore, we use measures of ex ante quality, prior experiences, financial and mentoring resources available and needs, to test possible competing hypotheses. Further, if the monetary incentives indeed crowd out the more prosocial candidates, it is also plausible that the type of projects that the applicants in the Cash treatment group propose are comparatively less prosocial. Concretely, in our setting, this would mean that their projects are relatively less focused on the needs of disadvantaged groups.

\subsection{Selection into the grant program}

In addition to the crowding in and crowding out effects, the reward cues are expected to also produce a straightforward incentive effect. Relative to the intrinsic reward cue only and ignoring any potential crowding out effects, the extrinsic reward cues are expected to encourage more candidates to apply, and applicants are expected to exert greater application effort (e.g., DellaVigna and Pope 2018). To the extent that such rewards raise the expected benefits of applying, we should observe more applicants. Furthermore, relative to the intrinsic rewards, the extrinsic rewards are more immediate (short term) and tangible. Indeed, processes that stimulate social change or produce a real social impact typically demand time. The delay of intrinsic rewards versus the immediacy of the extrinsic rewards provides an additional argument for why the extrinsic reward cues are likely to raise application effort and increase the number of applicants.

In our setting, candidates who are more strongly motivated to win the grant can undertake a number of actions, not all of which necessarily predict positive ex post social venture outcomes. On the one hand, 
candidates can expend more effort filling in the application form, like ensuring it is complete and submitted on time. On the other hand, they can also be more tempted to engage in self-promotion ${ }^{17}$ (Exley and Kessler 2019) or write the application in a way to please the evaluators (Murciano-Goroff, 2018). We expect that the cash, because of the more competitive market logic it primes (Vohs 2015), may well elicit more extensive self-promoting and opportunistic behaviors.

We therefore examine multiple measures of application effort: not just the application success rate, but also whether the application is complete, submitted on time, and the word count in the text responses in the full application. For example, we analyze the response to an open-ended question on non-financial recognition the applicant has received, where the applicant uses the opportunity to subjectively convey her own ability and past performance. Further, we also consider how much money the applicants requested, as asking for smaller amounts in our setting is one example of attempting to please the evaluators.

\subsection{The effects of selection on longer term social entrepreneurial outcomes}

Whether successful application outcomes (sorting and selection into the grant program) also predict actual social entrepreneurial outcomes is an empirical question. Because ex post all grantees receive the same treatment, we are able to identify the causal impact of selection at application stage on longer social entrepreneurial performance.

Table 1 summarizes our main behavioral predictions. If both crowding out (of prosocial candidates) and crowding in (of money-oriented candidates) effects happen, we expect overall fewer applicants following the extrinsic reward cues (Hypothesis 1). Moreover, those who sort into the grant competition will on average be more money-oriented, while those who opt out more pro-socially oriented (Hypothesis 2). It is therefore likely that applicants following the extrinsic reward cues will, on average, submit less pro-

\footnotetext{
${ }^{17}$ As discussed in Exley and Kessler (2019), self-promotion need not be considered negative, with the idea that positive self-assessments lead to engaging in more self-promotion. They cite Rudman (1998) who defines self-promotion as follows: "Designed to augment one's status and attractiveness, self-promotion includes pointing with pride to one's accomplishments, speaking directly about one's strengths and talents, and making internal rather than external attributions for achievements."
} 
social/more money-oriented projects (Hypothesis 3). At the same time, we expect the extrinsic reward cues to elicit greater application effort, and therefore produce a higher application success rate (Hypothesis 6). Without any crowding out effect, we should expect to see more candidates apply (Hypothesis 4). Because of the extrinsic rewards, the applicants may be also more inclined to adopt self-promoting behaviors (Hypothesis 5). We note that we expect the form of the extrinsic reward to also matter in our setting. Specifically, we expect that the effect of the in-kind rewards on sorting and application performance will be weaker relative to monetary rewards.

We acknowledge that several alternative behavioral mechanisms could have been prompted by our cues, such as a quality-selection effect (the ex-ante higher quality applicants select into the applicant pool) or selection based on ex ante mentoring and financial needs (if those who ex ante need more money or mentorship are more likely to differentially select into the applicant pool). However, as we discuss at length in our empirical section, we find no support for these alternative mechanisms. ${ }^{18}$ Now if, as suggested by Hypotheses 2,3,5 and 6, extrinsic reward cues lead to the selection of more money-oriented, self-promoting candidates, whose projects tend to be less concerned with prosocial issues but who exerted greater application effort, then any differences in longer term outcomes must be due to this selection effect.

\section{Data and Empirical Strategy}

\subsection{Data}

Our sample is comprised of all 431 candidates who submitted an EOI between January 1, 2015 and January 1, 2016. We gathered detailed information on each candidate making use of four primary data sources: (1) the initial expressions of interest (or EOIs), (2) the full applications submitted, (3) additional

\footnotetext{
${ }^{18}$ In line with the framing literature on subjects' misperception in public good setting (e.g. Andreoni 1995, Houser and Kuzban 2002 or Fosgaard et al. 2017), we cannot fully rule out that applicants are not underestimating the other potential benefits when one is made salient. It is however unclear if, and to what extent, misperception should differ across treatments. Moreover, addressing this issue would require a new experimental design.
} 
administrative data sources, and (4) responses to an end-of-the-grant survey administered by our partner organization.

\section{(1) The Expressions of Interest (EOI)}

The EOI is submitted to the agency in the first step of the application process and provides us with ex ante (or prior to the intervention) information for each potential applicant. We use the demographic and other basic data about each applicant captured in the EOI, such as gender, location, and age, as well as its textual data, notably text descriptions of the purpose of the venture and what is unique about it, the applicant's skills and experience, and perceived needs.

Based on the field containing the applicant's response to the question, "Explain your venture and what is unique about it" in the EOI, linguistic indicators of the applicants' orientation and measures of effort were generated using automated text analysis. First, we used the software program Linguistic Inquiry and Word Count (LIWC) to create measures of self- and other-orientation ("I" and "They"), orientation to interact with others (e.g. communicating, connecting, helping) and money-orientation (e.g., cash, bill, revenue) based on this field. LIWC allows us to search for over 4,500 words or word stems that have been categorized by independent judges into over 70 linguistic dimensions, ranging from pronouns, emotions, to social and cognitive processes (Pennebaker et al. 2015).

We additionally used the DICTION text analysis software, which includes thematic dictionaries composed of over 10,000 words developed to measure different aspects of political discourse (Hart and Caroll 2014), which has been used in the entrepreneurship literature (e.g. Short and Palmer 2008; Allison, Allison, Davis, Short and Webb 2014). We focus on DICTION's word lists related to prosocial references in text, such as "collectives", "cooperation" and "exclusion". Table A3 in the Appendix provides the definitions of each linguistic measure from the LIWC and DICTION manuals.

Moreover, we created a measure of the readability of this field, as a proxy measure of the candidate's ex ante 'quality' or effort spent on the EOI. To do this, we used the R quanteda program that allows us to calculate a number of readability scores that have been used in recent economics and management literature, such as the Flesch Reading Ease, Flesch-Kincaid, Dale-Chall, Gunning Fog, and 
SMOG (Simple Measure of Gobbledegook) measures (see e.g. Hengel 2018 for more information). Finally, we use a word count of this field as a proxy measure of the candidate's ex ante effort expended, as it is a measure of level of detail and the amount of time the applicant spent formulating the idea (see e.g. Piezunka and Dahlander, 2019). The applicants' response to this question was limited to 200 words, compelling applicants to be concise but still informative. ${ }^{19}$

To create additional measures of applicant quality, we assessed prior work experience in the forprofit sector and/or social sector ${ }^{20}$ based on the answer given to the question: "What skills and experience make you the right person to ensure this venture is successful?" This was an open-ended question. Two researchers independently coded the responses to this question and given the high inter-rater reliability (kappa-statistic measure of interrater agreement for the two measures was above 0.97; see Table A1 for a detailed overview), we randomly selected one set of the ratings to include in the analysis. Our results are similar when we use the other set of the ratings instead.

We also created two needs-related measures, namely whether the applicant needed funding or mentoring, by coding responses they provided to the question: "What other plans do you have in place to ensure that your venture continues to be successful?" As shown in Table 2, the majority of EOI submitters did mention money as a need (over 50\%). However, only $13 \%$ mentioned the need for mentorship or support. Finally, we developed a proxy measure of the applicant's self-confidence based on the response given to a question about the potential social benefit of the applicant's venture, with possible choices being local, regional, national or international benefit. Answering that the venture would have national or international (as opposed to local or regional) benefit was considered to be a proxy for overconfidence. ${ }^{21}$

\footnotetext{
${ }^{19}$ We also explored other text-based measures of effort, such as counts of the number of typos. We used the R hunspell package to try to get a misspelling measure in the text responses in the full application. However, we found that the measures were not useful in the end because there were very true cases of misspellings, likely because applicants already used spellchecking capabilities in their Word Processing software

${ }^{20}$ When the respondent mentioned prior work experience in a social enterprise, we coded this as work experience in both for-profit and social sectors.

${ }^{21}$ The literature often stresses the positive link between overconfidence and innovative activities. However, Herz et al. (2014) have recently shown that whereas overoptimism is often positively as- sociated with innovation, judgmental confidence (i.e., the applicant's tendency to overestimate the precision of his or her information) is negatively linked to innovation. We consider that stating a national or international level for the applicant's venture benefits is a sign of judgmental confidence.
} 


\section{(2) The Full Application}

The full application form is submitted in the second stage of the application process after our email intervention (see Figure 1). We used these data not only to measure our main treatment effects, but also to construct detailed measures about the applicant's project or venture.

Applicants were informed in the email (see Appendix A5) about the deadline for submission, which was typically 30 days after receipt of the email. We use as a measure of effort the number of days before the deadline the full application was submitted. ${ }^{22}$

We also constructed a proxy for application effort using the word count of applicants' responses to two open-ended questions related to: (i) the non-financial support received and recognition of candidate's work (ii) the main challenges and how support will benefit the venture. ${ }^{23}$ The former in part also reflects the applicant's inclination to self-promote. We also create the readability measures described previously using these two fields as another measure of application effort.

The full application includes rich information about the venture, including: the sector the venture operates in, whether it has a legal structure, financial information (e.g. projected overall expenditure over the next 12 months, amount requested from the organization), and the venture's target beneficiaries. The majority of the full applicants are operating in the education (28.2\%) and health sectors (18.4\%), as well as housing, facilities, community development (12.6\%) (see Appendix Table A3).

Regarding targeted beneficiaries of the venture, we created a dummy variable indicating whether the target beneficiaries belong to a disadvantaged group such as minority groups or persons with disabilities or belong to more general groups such as adults and/or children. Note that entrepreneurial efforts that address the needs of disadvantaged groups and thus seek to improve social inclusion are widely perceived as pressing, and hugely important in terms of the societal impact that they can make. Today, most policy-

\footnotetext{
${ }^{22}$ Approximately $56 \%$ of the applicants submitted their applications after the 30 -day deadline.

${ }^{23}$ The applicant could also be invited to pitch their project in front of an Award panel. Whether or not the applicant was invited could have been another proxy for effort but unfortunately, we were not able to get access to this information.
} 
making bodies, such as the European Commission and OECD, regularly track whether an enterprise affects the lives of disadvantaged groups as a proxy measure for their societal impact.

Finally, to establish whether applicant's main challenges were money-related, social impact-related or business advice and support-related, we used again the textual responses to the question, "What are your main challenges in the next 12 months and how will working with us help you to deal with them?”. Two researchers independently coded the responses to this question. The consensus and consistent estimates reported in Table A1 suggest high inter-rater reliability.

\section{(3) Administrative data}

We used the archival records of our partner organization to ascertain which of the applicants were successful in obtaining a grant, which was 95 in total during the study period. We were also granted access to the detailed written assessments of all the rejected applications, which we also use as a proxy for application effort. Two researchers first independently created a classification of these rejection reasons, then agreed on one classification and finally revisited their initial coding of the agreed upon classification system. The Cohen's Kappa coefficient for the two main rejection reasons coded by the two researchers was 0.95 and 0.92, respectively, so interrater agreement was almost perfect (Landis and Koch 1977). Finally, we also matched all EOI submissions to administrative data from the UK government from Companies House and Charity Register ${ }^{24}$ to establish whether the venture had registered as a Community Interest Company, Limited Company, Charity or other, and whether (or not) it had been dissolved (as of September 2017). ${ }^{25}$

\section{(4) End-of-grant survey responses}

The end-of-grant survey is run 12 months after grantees receiving the initial grant. Most questions use Likert scale response anchors and ask about the perceived efficacy of and satisfaction with the grant program. We focus on the handful of questions that asked about the economic performance (such as total income earned) and social impact of the grantee's venture over the prior 12 months. The overall response

\footnotetext{
${ }^{24} \mathrm{https}: / \mathrm{www}$.gov.uk/government/organisations/companies-house and https://www.gov.uk/find-charity-information

${ }^{25}$ We also updated this search for the award winners only in May-June 2019.
} 
rate to the end-of-grant survey was quite high (67\%, or 64 of the 95 grantees completing the survey). There were no significant differences across the 3 treatment groups in response rates to the survey, which alleviates concerns about non-response bias. Furthermore, we find no evidence that the survey data is systematically biased due to measurement error, or distortions in the assessment grantees make of their venture performance. Money-oriented grantees, for instance, did not systematically report higher values for performance outcomes. Taken together, these findings bolster the reliability of our survey data.

Out of the 431 EOI-candidates, 290 subsequently submitted a full application and 95 ultimately received the grant, that is, $22 \%$ of applicants submitting EOIs ultimately received grants (success rate). Table 2 shows our main baseline variables and provides a randomization balance check. The majority of candidates were female and about $15-17 \%$ resided in London. Candidates were on average 40 years old. The word count of the initial EOI (specifically of the responses to the main question: "Explain your venture and what is unique about it") was about 168 words (the word limit was 200). Our randomization check indicates that the groups were balanced on 11 out of 12 candidates' observable characteristics. We present both the basic experimental results and results including controls for our baseline characteristics and time controls, particularly given that there is a slightly higher share of female applicants in the Social group.

\subsection{Empirical Model}

The randomization allows us to estimate the pooled causal effect of receiving an extrinsic reward treatment (Cash or Support) relative to the intrinsic reward treatment (Social):

$$
Y_{i}=\alpha+\beta_{1} \text { ExtrinsicReward }_{i}+\gamma \boldsymbol{X}_{i}+u_{i}
$$

where $Y_{i}$ is an outcome measure for individual candidate i, ExtrinsicReward is a dummy variable that equals 1 if a candidate was assigned to receive the treatment email emphasizing an extrinsic reward (Cash or Support), and $X_{i}$ is the vector of controls (gender, age, London location, and time controls, including dummies for week of the EOI application and dummies for the date of the full application's deadline).The term $\beta_{1}$ is the pooled effect of receiving either type of reward cue compared to the Social cue. The Social 
treatment group serves as the control group in our setting since the social impact or intrinsic cue coincides with the standard frame conventionally used in outreach materials by the grant-making agency.

We also run the following regression to estimate the separate effect of receiving each of the extrinsic reward (Cash or Support) cues:

$$
Y_{i}=\alpha+\theta_{1} \operatorname{Cash}_{i}+\theta_{2} \text { Support }_{i}+\gamma \boldsymbol{X}_{i}+u_{i}
$$

where $\theta_{1}$ is the effect of the Cash cue and $\theta_{2}$ is the effect of receiving the Support cue. In specifications using endline survey data where we have multiple outcomes of the firm's performance, in order to test the joint significance of the treatments, we follow the approach in Clingingsmith et al. (2009) and calculate the average standardized effect size using the seemingly-unrelated regression framework, which accounts for covariance across estimates across groups of outcome measures (in our case, measures based either on the full application or the end of grant survey) (Robert, 2010).

Next, to examine the sorting effects, we also run regressions of the following form, where the dependent variable is a dummy variable indicating that the individual submitted a full application and we interact our treatment group dummies with various measures of individual characteristics from the EOI (i.e., ex ante treatment data):

$$
\begin{gathered}
Y_{i}=\alpha+\delta_{1} \text { ExtrinsicRewards }_{i}+\delta_{2} \text { ExtrinsicReward }_{i} * \text { Characteristic }_{i}+\delta_{3} \text { Characteristic }_{i}+ \\
\gamma X_{i}+u_{i}
\end{gathered}
$$

Here, our main characteristics of interest are the ex ante treatment measures from the EOI, such as linguistic measures of orientation of the candidates, so that $\delta_{2}$ will estimate differences between the applicants and non-applicants in these orientations across the treatment groups. We also estimate this regression by separating the treatment groups, as in (2). 


\section{Results}

Following the behavioral hypotheses outlined in Section 3, we next report on our empirical results. First we estimate the impact of extrinsic incentive cues on the sorting of individual candidates into submitting a full application (and proceeding in the grant competition) (H1-H3). Then we estimate whether the treatments impacted application effort and the likelihood of being selected into the grant program (H4H6). Finally, we explore whether the selection of candidates at the application stage had an impact on the performance of the grantees at the end of the one-year grant period.

\subsection{Effect of Extrinsic Rewards on Sorting Into and Out of the Grant Competition}

First, we look at sorting into the grant competition. Figure 2 shows the raw share of individuals who submitted an EOI who then (after our treatments) subsequently submitted full applications by treatment group. This provides initial evidence of one of our main results - that the Cash treatment led to fewer candidates applying.

Next, we turn to our regression analysis, where we can include the control variables discussed in Section 4.2. Panel A of Table 3 shows the pooled reward treatment (Cash and Support combined) relative to the Social group, and Panel B shows each treatment separately. In Table 3, Panel A, Column 1 shows that fewer candidates submitted a full application (9.4 percentage points) in the pooled reward treatment groups relative to the Social group. This effect is mainly driven by Cash treatment, with the effects in Panel B showing those in were 14.5 percentage points less likely to submit a full application than those in the Social group. The submission rate in the control group was 71 percent, so this reflects a 20 percent decline in applications in the Cash group. We see no significant difference in the application rates between Support and Social treatment groups. This result is consistent with $\mathrm{H} 1$ and not consistent with $\mathrm{H} 4$, suggesting that the extrinsic rewards indeed produced a strong crowding out effect.

Next, we examine whether the extrinsic reward cues impacted the sorting of individual candidates into the applicant pool, i.e. who opted in and who opted out of the competition. We begin by estimating the 
selection effects using the orientation measures based on the text responses to the EOI that provide, prior to the intervention, information for each potential applicant (these measures are described in Section 4.1). Figures $3 \mathrm{a}$ and $3 \mathrm{~b}$ provide initial suggestive evidence about these selection effects. These figures show the raw mean differences in the number of "money" or "collectives" words used in the EOIs (prior to the treatments) for those who submitted a full application (applicants) and those who did not (non-applicants). Figure 3a shows that applicants in the Cash treatment use slightly more "money words" in the EOI compared to non-applicants, while applicants in the Support and Social groups were less likely to use "money words" compared to non-applicants. Figure $3 \mathrm{~b}$ shows that for a measure of pro-sociality, the use of "collectives" words in the Cash group was lower for applicants compared to non-applicants, while it was higher for applicants compared to non-applicants in the Support and Social groups. The confidence intervals in these raw mean differences are quite large so we cannot make any conclusions from these figures alone, but the results suggest that the extrinsic monetary cue "crowded out" the less money-oriented, more prosocial candidates, but also "crowded in" the more money-oriented, less prosocial candidates.

To test the statistical significance of these effects of sorting in terms of individuals' prosocial versus money orientation, in Table 4, we estimate regressions interacting each treatment group with a dummy indicating the ex-ante measure of the candidate's orientation from the EOI, with the dependent variable being whether the candidate submitted a full application or not (equation 3). The interaction terms of the “orientation" measure and the treatment dummies are the coefficients of interest. Column 4, Panel B, shows that the individuals in the Cash treatment group who used more money words in their EOI were more likely to submit a full application, or opt-in following the extrinsic monetary reward cue.

Moreover, in Column 5, we see that the more prosocial individuals (using "collectives" as a proxy for social orientation) in the Cash treatment were more likely to opt-out and not submit a full application. ${ }^{26}$ This last result is in line with the finding that the full applications submitted by the applicants in the Cash

\footnotetext{
${ }^{26}$ Table 4 further shows that the coefficients of interest for the other proxy measures of social orientation (specifically, other-orientation, orientation towards interacting, cooperation, and liberation) were consistent with our main result, though not statistically significant.
} 
treatment were 21.8 percentage points less likely to report that disadvantaged groups benefit from their activity (see Column 6 of Table 3) compared to the full applications submitted in the Social group. It lends additional support to the notion that extrinsic rewards crowded in the less prosocial, and in the case of the monetary reward cue, more money-oriented candidates. This is in line with our hypotheses 2 and 3.

We next explore the nature of this sorting further in terms of the type and needs of the venture, and the skills and experience of the applicant. First, we look at the effects on the targeted beneficiary of the venture. Here, we use information on whether the applicant indicated on the full application that a 'disadvantaged' group would benefit as a result of the venture's activities, including answering yes to either "minority groups and other previously excluded groups" or "persons with disabilities". Table 3, Column 6 Panel B, shows that full applications submitted by the applicants in the Cash group were 21.8 percentage points less likely to report that a disadvantaged group would benefit from their activity. This suggests that the extrinsic reward cues crowded in the less prosocial candidates (Hypothesis 2).

Consistent with these effects, in Table 5 we estimate the effects on the main type of challenge the applicant faces (from a text response on the full application asking them to describe their 'Main challenges and how support will benefit the venture'). This was coded as either a 'Money', 'Support' or 'Social' challenge. The results in Panel B, Column 3, show that the individuals in the Cash treatment group were 11 percentage points more likely to indicate a Social challenge, i.e. needing support to measure or improve their social impact. These 'challenge'-measures are based on self-reported fields in the application, rather than clean ex ante measures, and thus may be influenced by the cue itself; however, this correlation is nevertheless consistent with our main finding that the extrinsic cues elicited a greater response from candidates who were more money-oriented and less socially-oriented, and thus more likely to require help to improve along this dimension.

We also estimate the extent of selection effects in terms of quality and other characteristics of applicants vs. non-applicants discussed in Section 4.1. We do not find any evidence of sorting on other observable measures regarding the type of venture, such as the legal structure (Table 3, Column 7), financial 
needs (Table 3, Column 8), or the sector the venture operates in (Table A3). ${ }^{27}$ We also do not find any evidence of sorting in response to the treatments in terms of skills, experience, or other observable characteristics of the candidates. Table A2 displays the means of different characteristics of the three treatment groups among applicants only in the first three columns and tests whether the means are statistically different across groups in the next three columns. While there does seem to be a higher share of females submitting full applications in the Social group, this was also the group for which this share was slightly higher after randomization. Overall, there is no evidence of selection in terms of these observable characteristics on the EOI.

Next, in Table A4, we show these selection results in a regression framework (equation 4) for these characteristics as well as measures of skill and experience and overconfidence, measured by whether the candidate views the benefit of their venture as International or National. The results show that there are no significant differences in terms of differential likelihood of applying related to prior for-profit sector or social sector experience and/or social enterprise sector work experience, nor in terms of overconfidence.

In sum, we find strong evidence that the Cash reward cue led to fewer candidates to apply (Hypothesis 1, not Hypothesis 4) and a "crowding out" of the more prosocial candidates and a "crowding in" of the more money-oriented ones (Hypothesis 2). These effects are limited to the pure extrinsic rewards cue (Cash), as we do not find evidence that the in-kind rewards cue (Support) crowded out prosocial candidates, although it did lead somewhat, but not significantly so, to fewer candidates applying.

\subsection{Effect of Extrinsic Rewards on Selection Into the Grant Program}

Next, we turn to selection into the grant program, i.e. success of the application. Table 3, Panel A, Column 2 shows that emphasizing the extrinsic rewards (either Cash or Support) increased the share of full applications that were successful in obtaining the grant by 14.2 percentage points relative to the share of full applications that were successful in the Social group. Panel B shows the estimated effects are similar

\footnotetext{
${ }^{27}$ One of the 13 sectors shows a significant difference for the Cash group (Supply chain services) but the share of applicants reporting this sector is very small in the control group $(2.9 \%)$.
} 
in both the Cash and Support groups. As discussed in Section 3, this can be due to greater self-promotion (Hypothesis 5) or greater application effort in response to the reward cues (Hypothesis 6).

As described in Section 4.1, we examine several proxy measures of application effort. First, we estimate the effect of the treatments on the word count of applicants' responses to two open-ended questions related to: (i) the non-financial support received and prior recognition of candidate's work (with the example provided on the application of e.g. winning a prize) and (ii) the main challenges and how support will benefit the venture. The treatment effect on these measures are presented in Table 3, columns 3 and 4 . The results show that applicants in the Cash treatment group tended to use more words on average in these fields, but this effect is only statistically significant for the answer to non-financial support on recognition. Here, we find that applicants in the Cash group used on average approximately 31 more words relative to the Social group to describe their prior non-financial support or recognition received (in the full application), while prior to the intervention there were no significant differences in EOI word count (see Table 2). ${ }^{28}$ Further, we find no difference in selection into the applicant pool based on actual professional experience again measured prior to the intervention (Table A4). These results suggest that applicants in the Cash group were more likely to expend efforts in self-promotion by reporting more text in the field that reflects prior achievements.

We also find that those in the Cash group were requesting a smaller amount of funding from the grant-making agency (Table 3, Column 9). The Cash cue led to approximately $18 \%$ less funding requested compared to the Social group. The average amount requested in the Social group was in fact almost $£ 7,000$, or $£ 2,000$ more than the grant amount, meaning that applicants from the Cash group were closer in their request to the actual monetary amount of the grant. This suggests a more precise reading of the application

\footnotetext{
${ }^{28}$ We also examined other measures of effort described in Section 4.1, including readability measures of the EOI text, but did not find significant differences between the groups.
} 
and grant materials, as opposed to differences in funding needs, as we find no significant differences in projected budget (Column 8) or sorting on ex ante the financial (or mentorship) needs. ${ }^{29}$

We next turn to other measures of application effort. We created the readability measures described in Section 4.1 using the two text fields in the full application as another measure of application effort. Here we find no differences among the treatment groups (Table 3, Column 5), although the negative coefficients suggest that the reward cues would lead to lower readability or more complex text. ${ }^{30}$

Next, we examine the timeliness of the submission of the full application. As discussed in Section 4.1, applicants were informed about the deadline for submission of the full application, which was typically 30 days after receipt of the email. We use as a measure of effort the number of days relative to the deadline the full application was submitted. Table 3, Column 6 shows that applicants in the Support group submitted their full applications 4 days earlier than applicants in the Social group. The average number of days relative to the deadline was 2.4 in the Social group, meaning that applicants submitted their applications late on average. This means that the Support cue led to more applications submitted prior to the deadline. We find no effects here for the Cash cue on timeliness.

Finally, we use the data on the reason for an application to not be successful, or the reasons for rejection discussed in Section 4.1. We compare the effect of the reward cues on the type of the reported rejection reasons provided by the evaluation committee. As shown in Table A7, we find that applications in the Cash group were significantly less likely to be rejected for being incomplete (usually because the application form was 'not filled in properly').

\footnotetext{
${ }^{29}$ We use the same coded measures of needs from the EOI discussed in Section 4.1. We estimate regressions as in equation 3 where the characteristic is money or mentoring need from the EOI. We do not find any significant differences, indicating there was no sorting based on needs.

${ }^{30}$ We present the results for the Flesch Reading Ease measure, which considers text with shorter words and sentences to be more readable, but none of the other measures discussed in Section 4.1 show significant differences. However, these measures may not be capturing application effort well for several reasons, such as a short amount of text in the full application with which to calculate the measure. Moreover, readability may not correlate well with quality or content of the text. For the Flesch Reading Ease, for example, zero means "practically unreadable" and 100 means "extremely easy." In our sample, the average in the control group is 35, which is in the "Difficult to Read" range, indicating it would require College Level education. For example, the Harvard Law Review has low readability score of 32 (more difficult to read) while Sports Illustrated has a higher score (more readable) of 63 (Stewart, 2003).
} 
In sum, these findings lend empirical support to hypotheses H5 and H6. Extrinsic rewards, especially extrinsic monetary reward cues, elicited greater application effort. Specifically, the applications following the cash cue were indeed more likely to be complete, to use more words (particularly to subjectively describe their own achievements, or self-promoting behavior) and request lower money amounts in line with the grant amount. The applications following the support cue were more likely to be submitted on time; however, no further evidence of greater effort spent was found. On average the success rate was significantly higher in both Cash and Support groups, despite only weak evidence of increased application effort following the support cue. Our findings thus demonstrate that extrinsic incentives can elicit higher performance at the application stage, especially by more money-oriented individuals and candidates more likely to self-promote themselves.

Altogether, our results seem to demonstrate that subtle extrinsic reward cues can in part motivate greater effort by candidates at the application stage who are then more successful in receiving the grant. At the same time, these rewards cues seem to also crowd in the more money-oriented candidates and crowd out their more prosocial counterparts. Whether these application effort and selection effects have any impact on the performance of the social enterprise is a question we turn to next.

\subsection{Effects of Selection on Longer-term Social Entrepreneurial Outcomes}

Table 6 provides the main regression results showing whether the performance of successful applicants measured in the end-of-grant survey differed by treatment group. ${ }^{31}$ Since many social ventures work to improve labor market integration or labor market outcomes more generally, one commonly used measure of social performance is the venture's ability to help people find a job. We find that compared to the candidates in the Social group, the grant winners in the Cash group had helped significantly fewer people to find a job over the past 12 months. They also spent on average nearly 8 hours less per week

\footnotetext{
${ }^{31} \mathrm{We}$ also matched all EOI submitters to administrative data from Companies House and Charity Register as another longer-run outcome by matching on the reported venture names from the EOI, however the results were not informative as we had relatively few matches leading to noisy estimates.
} 
working on their venture and had served approximately 2.6 fewer beneficiaries. The estimates are very similar when including broad controls for the sector (e.g. education or environment) and issue area of the venture (e.g. equality and empowerment, access to education or community development). The average standardized treatment effect over all these outcomes from the end-of-grant survey is -0.678 and significantly different from zero at the 1 percent level.

We would ideally like to complement these quantitative measures with more qualitative results on aspects such as the quality of the new jobs created or kinds of help provided to beneficiaries. Absent such data, we are able to look at self-reported answers to questions about the broader social impacts of the venture, such as the type of help offered to people. However, these are binary yes/no questions and most of the grant recipients report doing these activities, and thus we do not observe much variation in the data. In Table A8 we present the regression estimates for these measures, and we do not see any significant differences by treatment group. However, we note that the means of these variables are quite high, with the share of the sample reporting that they did the activity being over $50 \%$ for all 6 measures, and on average the respondents did 4 out of 6 . For example, for the question on whether the venture had 'help(ed) people connect with others they might not otherwise meet', $83 \%$ of the respondents said their venture did this. Thus, most of the ventures are reporting that they had these social impact effects, which may explain why we don't see differences across the treatment groups.

In sum, from quantitative measures from the end-of-grant survey, it seems that the grant winners in the extrinsic reward groups, despite their apparent higher effort at the application stage, fared worse one year later than those in the Social group who made it to this stage. This performance difference cannot be explained by an incentive effect once selected into the grant program, since all grantees ultimately received the same rewards. It is likely the result of selection at the application stage, both in terms of who entered the applicant pool, and who became a grantee. Our results suggest that the crowding out of the more prosocial candidates and crowding in of the more money-oriented candidates contributed to worse performance outcomes. Our results also suggest that self-promoting behavior (Cash treatment) or being on time (Support treatment) at the application stage are certainly poor predictors of longer-term social 
entrepreneurial success. Our data, however, do not allow us to pinpoint the dimension along which Support may have produced differential selection.

\section{Discussion}

Our results provide evidence that extrinsic incentive cues can promote effort and performance in the context of a grant competition for social entrepreneurial start-ups, yet they may also carry (unintended) costs. We found that these extrinsic cues, primarily the pure monetary cues, lowered application rates, and crowded in the relatively more money-oriented applicants, while crowding out their more prosocial, less money-oriented counterparts. The extrinsic reward cues led to more successful applications, or selection into the grant program. This appears to result from greater applicant effort, including being more timely and complete in the application submissions, but also more self-promotion by reporting more extensively on prior achievements.

We then find that grantees that had sorted into the applicant pool following the extrinsic incentive cues were in fact less successful at running a social enterprise, despite having submitted superior proposals. They had helped fewer people find a job in the previous 12 months relative to grant winners in the Social group and reached significantly fewer beneficiaries. This performance difference cannot be explained by an incentive effect once selected into the grant program, since all grantees ultimately received the same rewards. Our results suggest that the crowding out of prosocial applicants at the application stage, combined with selection into the grant program of more self-promoting individuals, contributed to worse performance outcomes. We generally find weaker effects of the in-kind rewards compared to the pure extrinsic rewards, but the data available to us does not allow us to pinpoint the dimension along which the Support cue may have produced differential selection. This would be a fruitful area for future research to understand how inkind rewards like mentoring impact social entrepreneurs' (application) behavior.

Our results highlight the critical role of intrinsic motives to the performance of social entrepreneurial start-ups and provide evidence that typically-used extrinsic incentives to promote the 
development of successful social enterprises may in fact be counterproductive. This suggests that ultimately a strong prosocial orientation may be critical to nascent social entrepreneurial success. Further, our findings also suggest that emphasizing extrinsic reward cues is unlikely to be sufficient to motivate greater effort throughout a one-year start-up phase, and may elicit self-promoting behaviors, which seem to be a weak predictor of ex post actual performance. Using such extrinsic reward cues may thus ultimately backfire if the goal is to stimulate successful social entrepreneurial outcomes.

Operational efficiency is a focal concern to our partner organization specifically, and many support programs more generally. Programs with a two-stage application process often systematically monitor: (i) the percentage of candidates that passed the first selection round but failed to submit a full application (costly leakage), and (ii) the overall success of the grant winners at the end of the support period (program effectiveness). Our results reveal that a subtle change in a grant program's framing (in between selection rounds), in particular one stressing the potential extrinsic rewards, can increase "leakage" and alter the composition of the grant winners in ways that are consequential to nascent social entrepreneurial success and the real societal impact they make. Such a program frame may thus inadvertently deteriorate operational efficiency.

We often think of intrinsic motivation as a key input to performance of mission-driven organizations especially (Grant and Sumanth 2009, Perry and Hondeghem 2008, Riggio and Taylor 2000). Yet, a recent stream of literature (e.g. Henderson and Van den Steen 2015; Gartenberg, Prat and Serafeim 2019) suggests that purpose may also be an essential ingredient to corporate business success. Our findings underline the importance of intrinsic motivation to the performance of (nascent) social enterprises, hybrid organizations that are both mission-driven and business-like, and thus bridge these two separate strands of literature.

Previous empirical research on extrinsic incentives and prosocial behaviors has yielded mixed results. Our findings suggest that the effect of an extrinsic incentive cue is highly heterogeneous and varies with the prosocial inclination of targeted individuals. The trade-off between incentive effect and crowding out will critically also depend on whether sorting of individuals is possible. Further, our findings also 
suggest that the strength of the behavioral responses to extrinsic incentive cues will vary with the nature of the incentives at hand. In our setting, the extrinsic financial incentive cues elicited somewhat greater effort and produced stronger crowding-out effects than the value-equivalent extrinsic non-financial incentive cues. Finally, our findings give evidence of not just a crowding-out effect, but also a crowding-in effect, which is equally consequential but has in the literature received far less attention.

In terms of managerial and policy implications, our results can help organizations and managers working with social entrepreneurs to design programs that increase take-up and participation and more effectively target and support the type of social entrepreneurs that they wish to empower. Further, designers of policies and programs aimed at supporting social start-ups should be cognizant of the surprisingly large sorting and performance effects that their seemingly minor program frames may provoke and consider whether such effects are indeed well aligned with their social goals.

Our study is of course subject to limitations. Our study is limited to the effect of incentive cues on participation to one support program and thus generalizing our results should be done with caution. More systematic research on the efficacy of incentive cues within different support program and country contexts is needed. Further, it is plausible that the success of specific incentive cues may well depend on the organizational culture of the support agency that is using them. A good fit between organizational values and the incentive cue may actually have a key moderating effect on their efficacy (Andersson et al. 2017; Blader, Gartenberg and Prat 2020). Further, while the magnitude of our estimated effects is in line with related previous work, ${ }^{32}$ their significance level is overall quite weak. To strengthen the confidence in our findings, we need more replication studies (Brandon and List 2015). Further, while we believe that the applicant's self-image concerns suggest a plausible mechanism for the sorting effects, our empirical set-up did not allow us to provide more direct evidence on this.

\footnotetext{
32 Please see Hummel and Maedche (2019) and Benartzi et al. (2017) for recent reviews of nudges; and Bhargava and Manoli (2015), Blasco et al. (2019), Choi et al. (2017), Kessler and Milkman (2018) for examples of similar interventions with similar effect sizes found.
} 
Provided that our results are externally valid, the most direct out-of-sample implications of our results relate to situations where motivating employee social entrepreneurship are important concerns (Campbell et al. 2017). Business leaders, for instance, who value opportunities for their employees to work on corporate social initiatives or start-up social ventures, are well-advised to emphasize the intrinsic rewards and reduce or at least downplay the extrinsic rewards that they attach to these types of initiatives.

Our study raises intriguing questions for future research. Which program frame (or incentive cue) is most effective at attracting the best successful mainstream nascent entrepreneurs or employee entrepreneurs (Sauermann 2018)? Our experimental framework could be readily adapted to test and contrast the effects of distinct incentive cues on participation (sorting), and subsequent performance in these sorts of alternative settings. ${ }^{33}$ Can such subtle programs frames also alter the self-selection of early stage or more experienced social entrepreneurs as well? These are interesting questions that we hope researchers will pursue going forward.

\footnotetext{
${ }^{33}$ Relative to ex post evaluations, experimentation provides practitioners with a more proactive method to evaluate a program, in particular deepen understanding of the true motives that targeted groups hold and whether different motives matter to their success. This is welcome given apparently growing frustration and disinterest amongst policymakers about the use of ex post program evaluations. We thank policy analysts working at OECD for this comment.
} 


\section{References}

Allison TH, Davis BC, Short JC, Webb JW (2014) Crowdfunding in a prosocial microlending Environment: Examining the role of itrinsic versus extrinsic cues. Entrepreneurship Theory and Practice. 39(1):5373.

Andersson O, Huysentruyt M, Miettinen T, Stephan U (2017) Person-organization fit and incentives: A causal test. Management Science. 63(1):73-96.

Andreoni J (1995) Cooperation in public-goods experiments: Kindness or confusion? American Economic Review. 85:891-904.

Andreoni J, Payne AA (2011) Is crowding out due entirely to fundraising? Evidence from a panel of charities. Journal of Public Economics. 95(5):334-343

Ariely D, Bracha A, Meier S (2009) Doing good or doing well? Image motivation and monetary incentives in behaving prosocially. American Economic Review. 99(1):544-555.

Ashraf A, Bandiera O, Davenport E, Lee SS (2020) Losing prosociality in the quest for talent? Sorting, selection, and productivity in the delivery of public services. American Economic Review 110(5):1355-94.

Baumeister R (1998) The self. In The Handbook of Social Psychology, edited by Gilbert D., Fiske S., Lindzsey G. McGraw-Hill.

Bénabou R, Tirole J (2003) Intrinsic and extrinsic motivation. Review of Economic Studies. 70:489-520.

Bénabou R, Tirole J. (2006) Incentives and prosocial behavior. American economic review. 96(5):165278.

Benartzi S, Beshears J, Milkman KL, Sunstein CR, Thaler RH, Shankar M, Tucker-Ray W, Congdon WJ, Galing S (2017) Should governments invest more in nudging?. Psychological Science. 28(8):104155.

Besley T, Ghatak M (2005) Competition and incentives with motivated agents. American Economic Review, 93(5):616-636. 
Blader S, Gartenberg C, Prat A (2020) The contingent effect of management practices. The Review of Economic Studies. 87(2):721-49.

Blasco, A., Jung, O.S., Lakhani, K.R. and Menietti, M., 2019. Incentives for public goods inside organizations: Field experimental evidence. Journal of Economic Behavior \& Organization, 160, pp.214-229.

Bodner R., Prelec D (2003) Self-signaling and diagnostic utility in everyday decision making. In The Psychology of Economic Decisions. Vol. 1. Rationality and Well-being, edited by Brocas I, Carillo J. Oxford University Press, pp. 105-26.

Bosma N, Schott T, Terjesen S, Kew P (2016) GEM 2015 to 2016: Special topic report on social entrepreneurship. Report, Global Entrepreneurship Monitor, London.

Boudreau KJ, Lakhani KR (2016) Innovation experiments: Researching technical advance, knowledge production, and the design of supporting institutions. Innovation Policy and the Economy. 16(1):135167.

Bowles S (2016) The moral economy: Why good incentives are no substitute for good citizens (Yale University Press).

Bowles S, Polanía-Reyes S (2012) Economic incentives and social preferences: Substitutes or complements? Journal of Economic Literature. 50(2):368-425.

Brüggemann J, Bizer K (2016) Laboratory experiments in innovation research : a methodological overview and a review of the current literature. Journal of Innovation and Entrepreneurship. 5(24):1-13.

Brüggemann J, Proeger T (2017) The effectiveness of public subsidies for private innovations. An experimental approach. The BE Journal of Economic Analysis \& Policy. 17(4)

Bhargava S, Manoli D (2015) Psychological frictions and the incomplete take-up of social benefits:

Evidence from an IRS field experiment. American Economic Review. 105(11):3489-529. 
Blasco A, Jung OS, Lakhani KR, Menietti M (2019) Incentives for public goods inside organizations: Field experimental evidence. Journal of Economic Behavior and Organization. 1(160):214-29.

Bless H, Schwarz N (1998) Context effects in political judgement: Assimilation and contrast as a function of categorization processes. European Journal of Social Psychology. 28(2):159-172.

Brandon A, List JA (2015) Markets for replication. Proceedings of the National Academy of Sciences. 112(50):15267-8.

Campbell BA, Kryscynski D, Olson DM (2017) Bridging strategic human capital and employee entrepreneurship research: A labor market frictions approach. Strategic Entrepreneurship Journal. 11(3):344-356.

Cassar L, Meier S (2018) Nonmonetary Incentives and the Implications of Work as a Source of Meaning. Journal of Economic Perspectives, 32(3):215-238.

Chandra Y (2016) A rhetoric-orientation view of social entrepreneurship. Social Enterprise Journal. 12(2):161-200.

Choi JJ, Haisley E, Kurkoski J, Massey C (2017) Small cues change savings choices. Journal of Economic Behavior \& Organization. 142:378-395.

Clingingsmith D, Khwaja AI, Kremer M (2009) Estimating the impact of the Hajj: Religion and tolerance in Islam's global gathering. Quarterly Journal of Economics, 124(3):1133-1170.

Currie J, Gahvari F (2008) Transfers in cash and in-kind: Theory meets the data. Journal of Economic Literature. 46(2): 333-83.

Dal Bó E, Finan F, Rossi M (2013) Strengthening state capabilities: The role of financial incentives in the call to public service. Quarterly Journal of Economics. 128(3):1169-1218.

Dal Bó E, Hernández P, Mazzuca S (2015) The paradox of civilization: Pre-institutional sources of security and prosperity. Working paper, NBER No. 21829, Cambridge. 
Deci EL, Koestner R, Ryan RM (1999) A meta-analytic review of experiments examining the effects of extrinsic rewards on intrinsic motivation. Psychological bulletin. 125(6):627-668.

Deci, Edward L., Richard M. Ryan (1985) The general causality orientations scale: Self-determination in personality, Journal of research in personality 19, no. 2 (1985): 109-134.

DellaVigna S, Pope D (2018) What motivates effort? Evidence and expert forecasts. Review of Economic Studies. 85(2):1029-1069.

De Mel S, McKenzie D, Woodruff C (2014) Business training and female enterprise start-up, growth, and dynamics: Experimental evidence from Sri Lanka. Journal of Development Economics. 106(C):199210.

Deserranno E (2019) Financial incentives as signals: Experimental evidence from the recruitment of village promoters in Uganda. American Economic Journal: Applied Economics. 11(1):277-317.

Ederer F, Manso G (2013) Is pay-for-performance detrimental to innovation? Management Science. 59(7):1496-1513.

von Essen E, Huysentruyt M, Miettinen T Exploration in teams and the encouragement effect: Theory and experimental evidence. Management Science. Forthcoming.

Exley CL (2018) Incentives for prosocial behavior: the role of reputations. Management Science. 64(5):2460-2471

Exley CL, Kessler JB (2019) The gender gap in self-promotion (No. w26345). National Bureau of Economic Research.

Fosgaard MR, Fosgaard TR, Foss NJ (2017) Consumer or citizen? Prosocial behaviors in markets and nonmarkets. Social Choice and Welfare 49(2):231-53.

Frey BS (1994) How intrinsic motivation is crowded out and in. Rationality and Society. 6(3):334-352.

Ganguli I, Gaulé P, Guinan E, Lakhani K (2017) Do Scientists Care About Kudos? A Field Experiment on Status Rewards in Academia. Working paper, University of Massachusetts, Amherst. 
Gartenberg C, Prat A, Serafeim G (2019) Corporate purpose and financial performance. Organization Science. 30(1):1-8.

Germak AJ, Robinson JA (2014) Exploring the motivation of nascent social entrepreneurs. Journal of Social Entrepreneurship. 5(1):5-21.

Gneezy U, Meier S, Rey-Biel P (2011) When and why incentives (don't) work to modify behaviour. Journal Econonic Perspectives. 25(4):191-210.

Gneezy U, Rustichini A (2000) Pay enough or don't pay at all. Quarterly Journal of Economics. 115(3):791810.

Grant AM, Sumanth JJ (2009) Mission possible? The performance of prosocially motivated employees depends on manager trustworthiness. Journal of Applied Psychology. 94(4): 927-944.

Grillos T (2017) Economic vs non-material incentives for participation in an in-kind payments for ecosystem services program in Bolivia. Ecological Economics. 131:178-190.

Guzman G, Oh JJ and Sen A. 2020. What Motivates Innovative Entrepreneurs? Evidence from a Global Field Experiment. Management Science. Forthcoming.

Hart RP, Caroll CE (2014) DICTION 7 Help Manual. The text analysis program (Digitext Inc., Austin, Texas).

Heckathorn DD (1997) Respondent-driven sampling: a new approach to the study of hidden populations. Social problems. 44(2):174-199.

Henderson R, Van den Steen E (2015) Why do firms have "purpose"? The firm's role as a carrier of identity and reputation. American Economic Review: Papers and Proceedings. 105(5):326-330.

Hengel, E (2018). Publishing while Female. Are women held to higher standards? Evidence from peer review. Mimeo.

Herz H, Schunk D, Zehnder C (2014) How do judgmental overconfidence and overoptimism shape innovative activity? Games and Economic Behavior. 83(C):1-23. 
Houser D, Kurzban, R (2002) Revisiting kindness and confusion in public goods experiments. American Economic Review. 92:1062-69.

Hossain T, Li KK (2014) Crowding out in the labor market: A prosocial setting is necessary. Management Science. 60(5):1148-1160.

Hummel D, Maedche A (2019) How effective is nudging? A quantitative review on the effect sizes and limits of empirical nudging studies. Journal of Behavioral and Experimental Economics. 1(80):4758.

Huysentruyt M, Mair M, Stephan U (2016) Market-oriented and mission-focused: Social enterprises around the globe. Stanford Social Innovation Review (October 19), https://ssir.org/articles/entry/market oriented and mission focused social enterprises around th $\underline{\text { e globe }}$

Kessler JB, Milkman KL (2018) Identity in charitable giving. Management Science. 64:845-859

Kram KE (1985) Mentoring at work. Boston: Scott, Foresman.

Lacetera N, Macis M, Slonim R (2014) Rewarding volunteers: A field experiment. Management Science. 60(5):1107-1129.

Laffont JJ, Maskin E (1982) The Theory of Incentives: An Overview. Hildenbrand W, ed. Advances in Economic Theory (Cambridge, Cambridge University Press), 31-94.

Lazear BEP, Malmendier U, Weber RA (2012) Sorting in experiments with application to social preferences. American Economic Review: Applied Economics. 4(1):136-163.

Landis JR, Koch GG (1977) The measurement of observer agreement for categorical data. Biometrics $1: 159-74$.

Lieber EM, Lockwood LM (2018) Targeting with In-kind Transfers: Evidence from Medicaid Home Care. No. w24267. National Bureau of Economic Research.

List JA (2011) The market for charitable giving. Journal of Economic Perspectives. 25(2):157-180. 
Lyons, E. and Zhang, L., 2019. Trade-offs in motivating volunteer effort: Experimental evidence on voluntary contributions to science. PloS one, 14(11), p.e0224946.

Mair J, Marti I (2006) Social entrepreneurship research: A source of explanation, prediction, and delight. Journal of World Business, 41(1):36-44.

Manski CF (1993) Identification of endogenous social effects: The reflection problem. Review of Economic Studies. 60(3):531-542.

Murciano-Goroff R (2018) Missing women in Tech: The labor market for highly skilled software engineers, Mimeo.

Noe, R, Greenberger, DB, Wang, S (2002) Mentoring: What we know and where we might go. Research in Personnel and Human Resources Management. 21:129-173.

Laffont JJ, Maskin E (1982) The theory of incentives: An overview. Hildenbrand W, eds. Advances in Economics Theory (Cambridge Univeristy Press, Cambridge), 31-94.

OECD (2011) Fostering Innovation to Address Social Challenges. Report, Organisation for Economic Cooperation and Development, Paris.

Piezunka H, Dahlander L (2019) Idea rejected, tie formed: organizations' feedback on crowdsourced ideas. Academy of Management Journal. 62(2):503-530.

Pennebaker JW, Booth RJ, Boyd RL, Francis ME (2015) Linguistic Inquiry and Word Count: LIWC2015. (Pennebaker Conglomerates Inc, Austin, TX).

Perry JL, Hondeghem A (2008) Motivation in public management. The call of public service. Oxford University Press, Oxford.

Renko M (2013) Early challenges of nascent social entrepreneurs. Entrepreneurship Theory and Practice. 37(5):1045-1069.

Reynolds PD, Carter NM, Gartner WB, Greene PG (2004) The prevalence of nascent entrepreneurs in the United States: Evidence from the panel study of entrepreneurial dynamics. Small Business Economics. 23(4):263-284. 
Riggio RE, Taylor SJ (2000) Personality and communication skills as predictors of hospice nurse performance. Journal of Business and Psychology. 15(2):351-359.

Robert C (2010) AVG_EFFECT: Stata module to calculate mean (standardized) effect size across multiple outcomes $\quad$ Retrieved $\quad$ October 29 , https://EconPapers.repec.org/RePEc:boc:bocode:s457196

Roy AD (1951) Some thoughts on the distribution of earnings. Oxford Economic Papers. 3(2):135-146.

Rudman, L. A. (1998). Self-promotion as a risk factor for women: the costs and benefits of counter stereotypical impression management. Journal of personality and social psychology, 74(3): 629.

Sauermann H (2018) Fire in the belly? Employee motives and innovative performance in startups versus established firms. Strategic Entrepreneurship Journal. 12(4):423-454.

Short JC, Palmer TB (2008) The application of DICTION to content analysis research in strategic management. Organizational Research Methods. 11(4):727-752.

Stewart J (2003) Recalibrating the Flesch Readability Index for the twenty-first century. Bulletin of the International Cultural Research Institute of Chikushi Jogakuen University/Junior College. Retrieved from http://www. stewartenglish. com/Recalibrating_Abstract.pdf.

Titmuss RM (1972) The gift relationship: From human blood to social policy. Journal of Social Policy. 1(1):81-84.

Turban DB, Lee FK (2007) The role of personality in mentoring relationships. The handbook of mentoring at work: Theory, research, and practice. 9:21-50.

Vohs KD (2015) Money priming can change people's thoughts, feelings, motivations, and behaviors: An update on 10 years of experiments. Journal of Experimental Psychology: General. 144(4):e86-e93.

Wänke M, Bohner G, Jurkowitsch A (1997) There are many reasons to drive a BMW: Does imagined ease of argument generation influence attitudes? Journal of Consumer Research. 24(2):170-177.

Zahra SA, Gedajlovic E, Neubaum DO, Shulman JM (2009) A typology of social entrepreneurs: Motives, search processes and ethical challenges. Journal of Business Venturing. 24(5):519-532. 


\section{TABLES \& FIGURES}

Figure 1. Experimental design

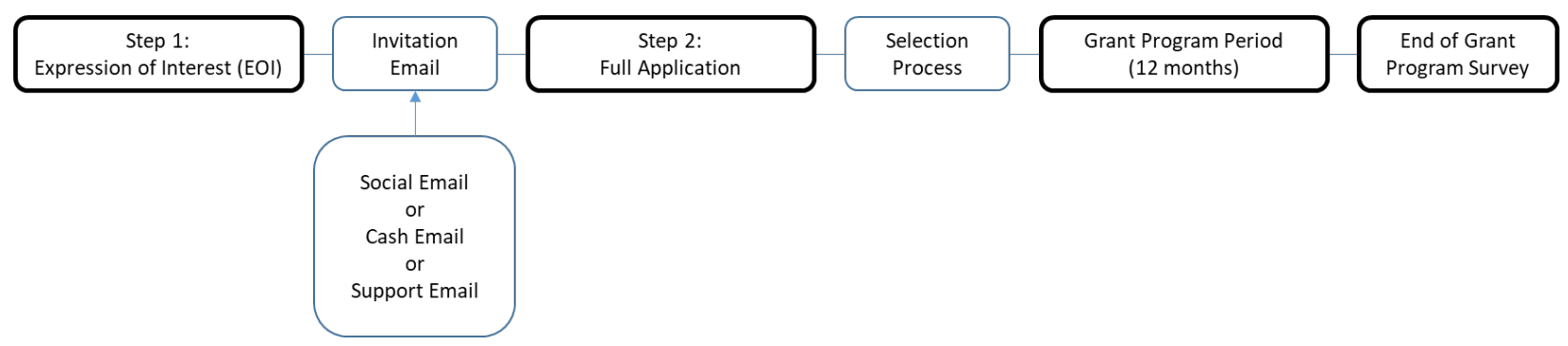

Figure 2. Share Submitting Full Applications by Treatment Group

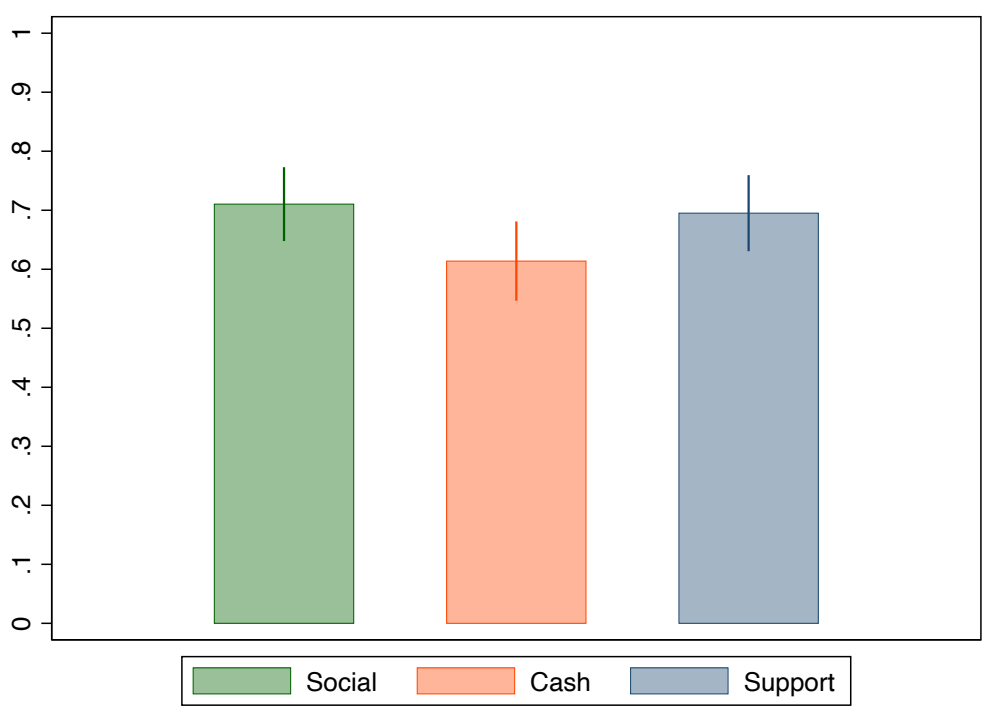

Notes: Raw share of EOI submitters (candidates) submitting a full application for each treatment group with $90 \%$ confidence intervals. 
Figure 3. Orientation of applicants vs. non-applicants based on EOI, by Treatment group (a) Money-Orientation

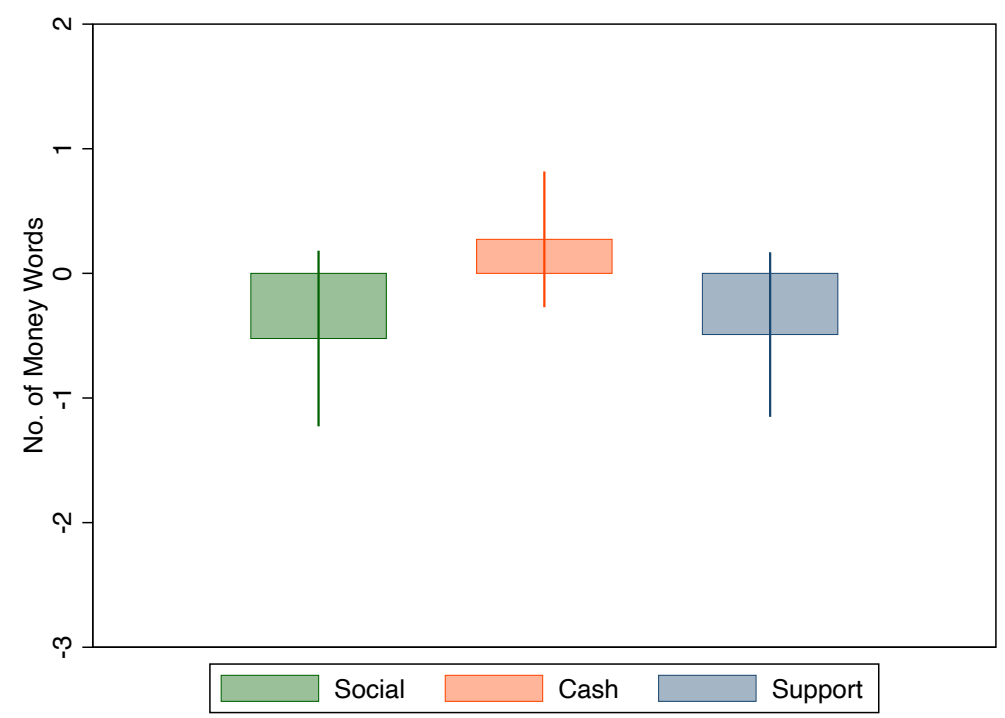

(b) Collectives-orientation

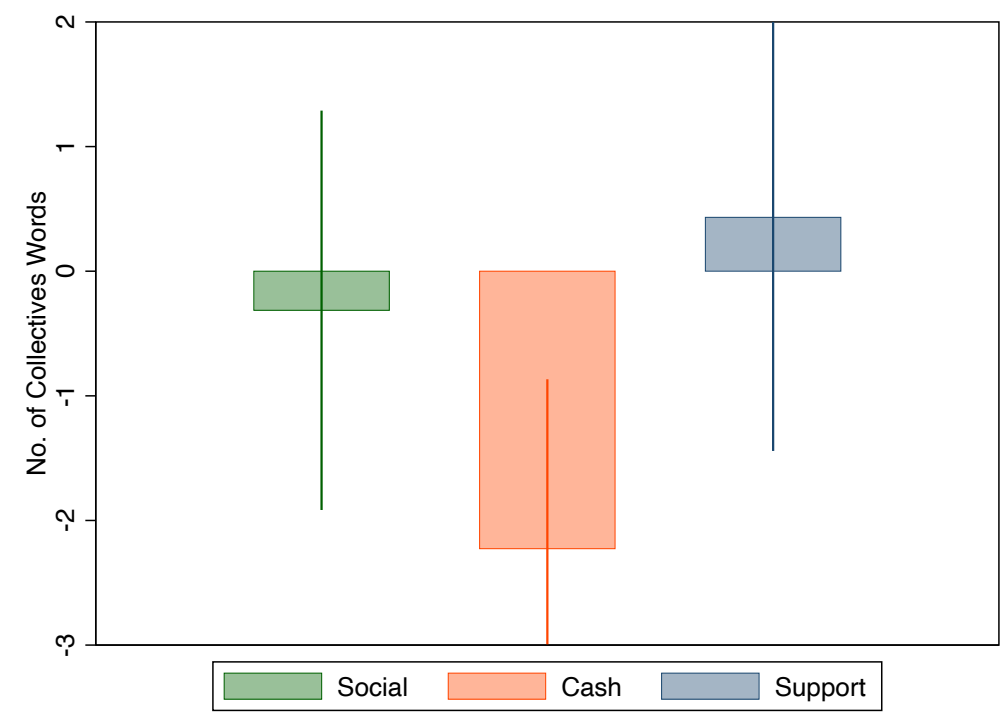

Notes. Difference in raw means of applicants' and non-applicants' (a) money and (b) collectives orientation for each treatment group with $90 \%$ confidence intervals. Orientation is the number of money or collective words used based on analysis of the text fields for the EOI question "Explain your venture and what is unique about it" using the software program Linguistic Inquiry and Word Count (LIWC) (Pennebaker et al. 2015) 
Table 1. Behavioral Hypotheses: Emphasizing Extrinsic Rewards relative to Intrinsic Rewards Only*

\begin{tabular}{lccc}
\hline Mechanisms & Number of applicants & Applicant's type & Application's type \\
\hline $\begin{array}{l}\text { Crowding out effect } \\
\text { and crowding in effect }\end{array}$ & $\begin{array}{c}\text { H1: Lower number } \\
\text { of applicants }\end{array}$ & $\begin{array}{c}\text { H2: Less socially-oriented } \\
\text { applicants and more } \\
\text { money-oriented applicants }\end{array}$ & $\begin{array}{c}\text { H3: Less pro-socially } \\
\text { oriented projects }\end{array}$ \\
$\begin{array}{l}\text { Standard incentive } \\
\text { effect }\end{array}$ & $\begin{array}{c}\text { H4: Higher number of } \\
\text { applicants }\end{array}$ & $\begin{array}{c}\text { H5: Applicants who are } \\
\text { more inclined to engage in } \\
\text { self-promotion }\end{array}$ & $\begin{array}{c}\text { H6: More application } \\
\text { effort spent and } \\
\text { subsequently higher } \\
\text { number of successful } \\
\text { applications }\end{array}$
\end{tabular}

\footnotetext{
Notes. ${ }^{*}$ We consider the Social treatment, where only the intrinsic rewards were made salient, as our control or comparison group. PIt is important to note that the net effect of crowding in and crowding out depends on the distribution of types within our study population, that is, the relative share of those who are relatively more strongly intrinsically motivated versus those who are relatively more strongly extrinsically motivated to apply and start-up a social enterprise. If we assume that our sample predominantly consists of individuals who value intrinsic rewards more, then the applicant pool is expected to shrink following the extrinsic reward cue.
} 
Table 2. Balance Check: Baseline Characteristics by Treatment Group based on EOI Data (N=431)

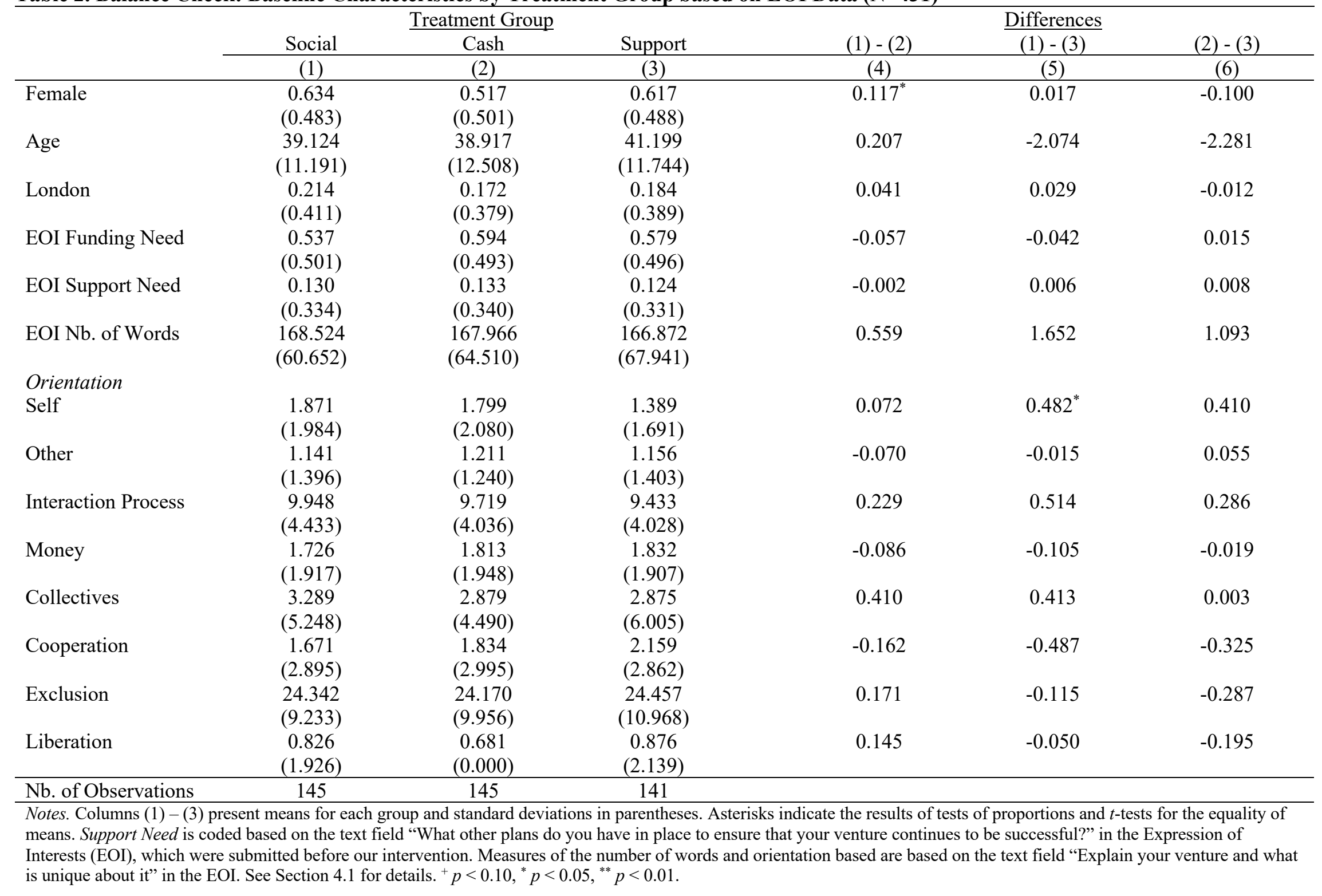


Table 3. Regression results: Treatment Effects on Application Outcomes

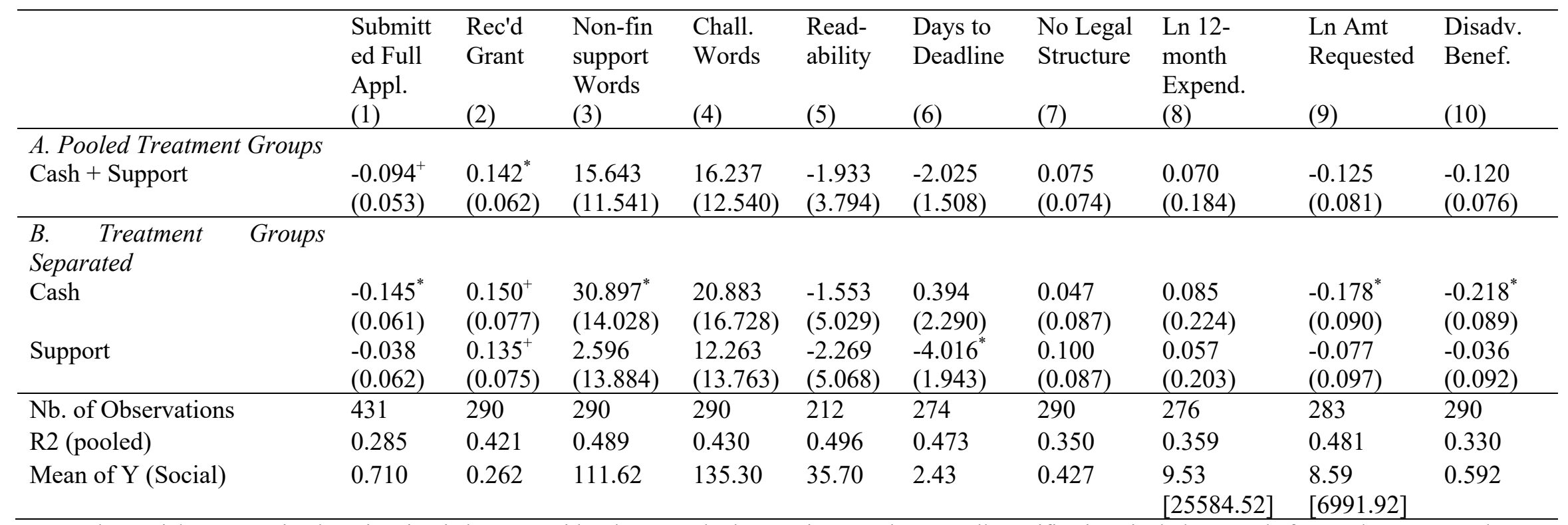

Notes. The Social group omitted. Estimation is by OLS with robust standard errors in parentheses. All specifications include controls for gender, age, London location, list, and time controls (dummies for week of the EOI application and dummies for the "30-day deadline to apply"). The dependent variables are: (1) whether the applicant submitted a full application; (2) whether the applicant was subsequently successful in receiving a grant; (3) number of words in the text response to the question about 'Non-financial support received and recognition of work' ("Who is currently providing you with support (non-financial) and in what ways? Has your work been recognized (for example by winning a prize)?") on the full application; (4) number of words in the text response to the question 'Main challenges and how support will benefit the venture' ("What are your main challenges in the next 12 months and how will working with us help you to deal with them?") on the full application; (5) Flesh Reading Ease readability measure of the previous 2 text fields on the full application; (6) number of days relative to the 30-day deadline to apply the applicant submitted their full application; (7) whether the applicant indicated on the full application that there was no legal structure for the venture; (8) log of the projected overall expenditure of the venture over the next 12 months (from the full application); (9) log of the amount requested from the support agency; and (10) whether the applicant indicated on the full application that a 'disadvantaged' group would benefit as a result of the venture's activities, including answering yes to either "Minority groups and other previously excluded groups" or "Persons with Disabilities". $+\mathrm{p}<0.10, * \mathrm{p}<0.05, * * \mathrm{p}<0.01$. 
Table 4. Regression Results: Treatment Effects on Ex Ante (EOI) Text Measures of Orientation

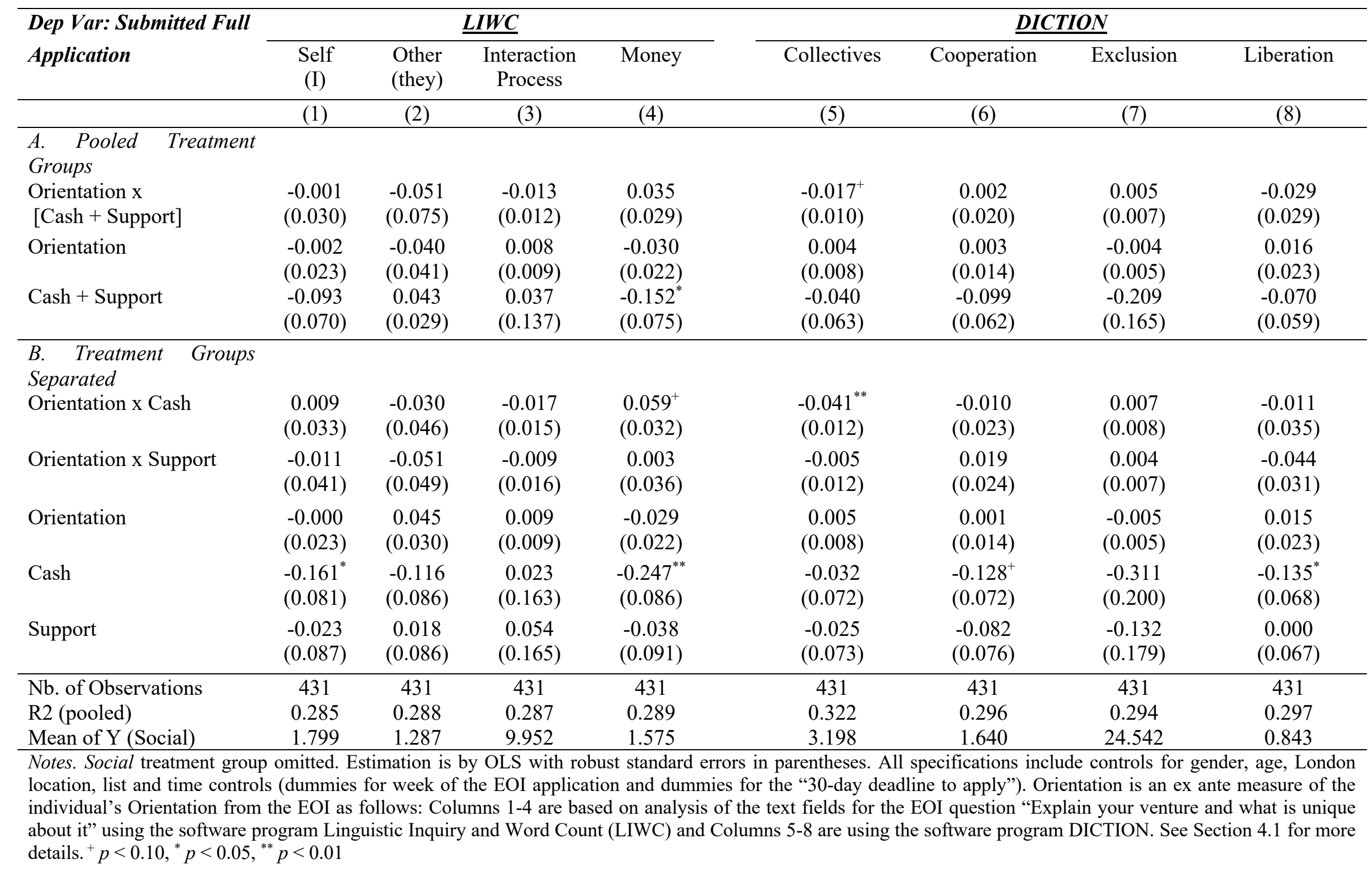


Table 5. Regression Results: Treatment Effects on Type of Challenge

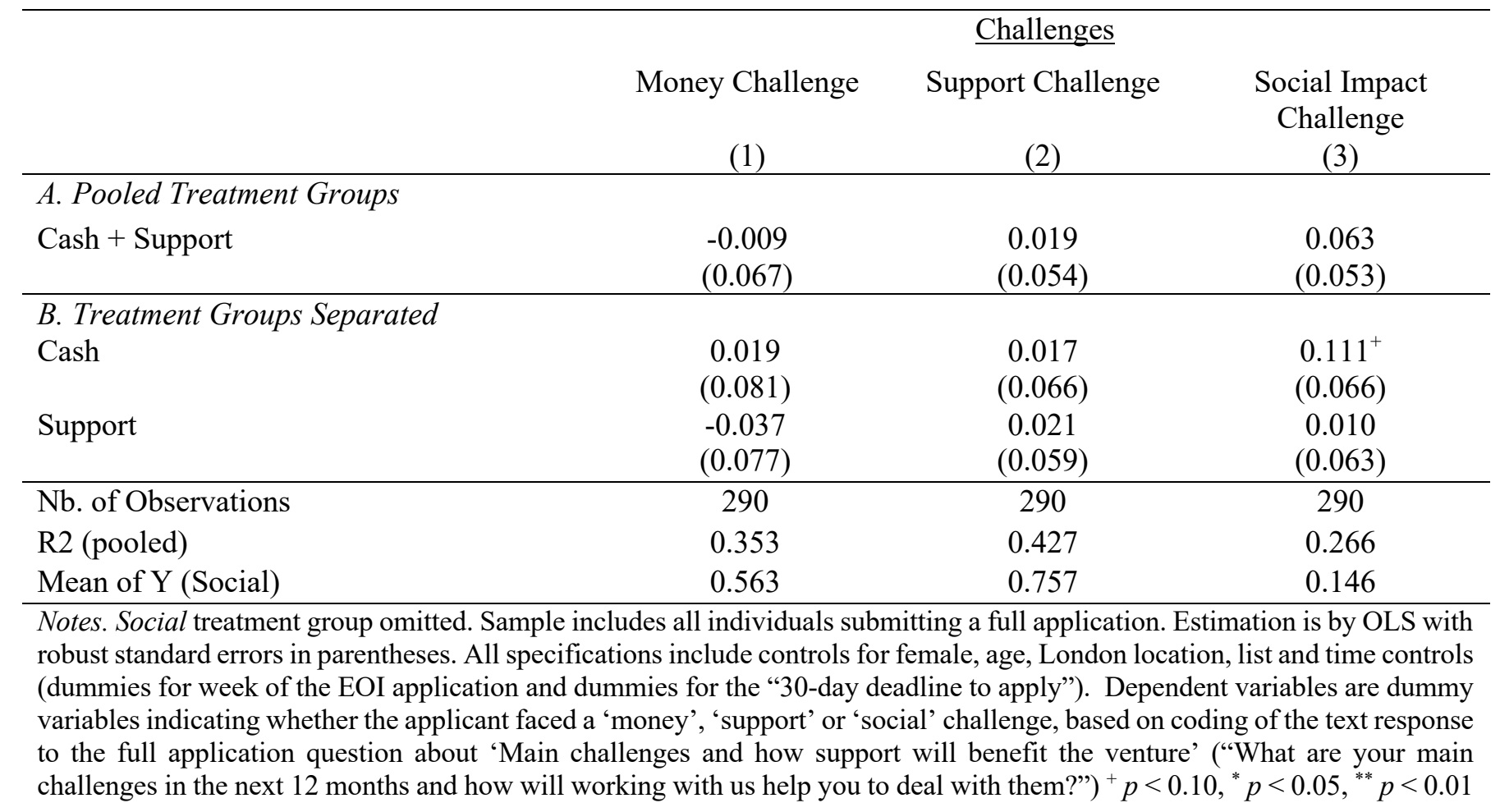


Table 6. Regression Results: End of Grant Survey (12-months Post-Grant)

\begin{tabular}{|c|c|c|c|c|c|c|c|c|}
\hline & Log Paid FT & Log Jobs & $\begin{array}{c}\text { Log } \\
\text { Trainees } \\
(3) \\
\end{array}$ & $\begin{array}{c}\text { Personal } \\
\text { Income } \\
(4) \\
\end{array}$ & $\begin{array}{c}\text { Weekly } \\
\text { Hours } \\
(5) \\
\end{array}$ & $\begin{array}{c}\text { Log Total } \\
\text { Income } \\
(6) \\
\end{array}$ & $\begin{array}{c}\text { Log } \\
\text { Total } \\
\text { Benef. } \\
(7) \\
\end{array}$ & $\begin{array}{c}\text { Average } \\
\text { Effect } \\
\text { Size } \\
(8) \\
\end{array}$ \\
\hline \multicolumn{9}{|c|}{$\begin{array}{l}\text { A. Pooled Treatment } \\
\text { Groups }\end{array}$} \\
\hline Cash + Support & $\begin{array}{l}-1.104 \\
(0.946)\end{array}$ & $\begin{array}{l}-2.642^{*} \\
(1.218)\end{array}$ & $\begin{array}{l}-0.780 \\
(1.350)\end{array}$ & $\begin{array}{l}-0.115 \\
(0.160) \\
\end{array}$ & $\begin{array}{l}-7.717^{+} \\
(4.202)\end{array}$ & $\begin{array}{l}-0.189 \\
(0.387)\end{array}$ & $\begin{array}{l}-2.605^{+} \\
(1.361) \\
\end{array}$ & $\begin{array}{l}-0.678^{* *} \\
(0.214) \\
\end{array}$ \\
\hline \multicolumn{9}{|l|}{$\begin{array}{l}\text { B. Treatment Groups } \\
\text { Separated }\end{array}$} \\
\hline Cash & $\begin{array}{l}-1.404 \\
(0.963)\end{array}$ & $\begin{array}{l}-3.613^{* *} \\
(1.280)\end{array}$ & $\begin{array}{l}-1.210 \\
(1.722)\end{array}$ & $\begin{array}{l}-0.152 \\
(0.173)\end{array}$ & $\begin{array}{l}-6.407 \\
(4.984)\end{array}$ & $\begin{array}{l}-0.315 \\
(0.355)\end{array}$ & $\begin{array}{l}-3.085^{+} \\
(1.635)\end{array}$ & $\begin{array}{l}-0.670^{* *} \\
(0.230)\end{array}$ \\
\hline Support & $\begin{array}{l}-0.887 \\
(1.088)\end{array}$ & $\begin{array}{l}-1.938 \\
(1.396)\end{array}$ & $\begin{array}{l}-0.468 \\
(1.411)\end{array}$ & $\begin{array}{l}-0.086 \\
(0.186)\end{array}$ & $\begin{array}{l}-8.527^{+} \\
(4.406)\end{array}$ & $\begin{array}{l}-0.108 \\
(0.489)\end{array}$ & $\begin{array}{l}-2.256 \\
(1.503)\end{array}$ & $\begin{array}{l}-0.569^{*} \\
(0.225)\end{array}$ \\
\hline $\mathrm{Nb}$. of Observations & 64 & 64 & 64 & 52 & 54 & 50 & 64 & 46 \\
\hline R2 (pooled) & 0.100 & 0.133 & 0.069 & 0.158 & 0.166 & 0.061 & 0.142 & \\
\hline Mean of Y (Social) & 0.44 & 5.89 & 27.67 & 0.4 & 30.8 & $15,662.3$ & 185.44 & \\
\hline $\begin{array}{l}\text { Notes. Social treatment } \\
\text { age, London location, a } \\
\text { variable are as follows: } \\
\text { people got jobs as a re } \\
\text { personal income from t } \\
\text { your venture's total ino } \\
\text { clients). }{ }^{+} p<0.10{ }^{*} p\end{array}$ & $\begin{array}{l}\text { omitted. Est } \\
\text { to education } \\
\text { ow many pai } \\
\text { f your work } \\
\text { ture?; (5) H } \\
\text { in the last } 12 \\
{ }^{* *} p<0.01 \text {. }\end{array}$ & $\begin{array}{l}\text { on is by C } \\
\text { e area of } t \\
\text { ff does yo } \\
\text { last } 12 \mathrm{r} \\
\text { any hours } \\
\text { ths?; (7) }\end{array}$ & 3) $\mathrm{H}$ & $\begin{array}{l}\text { indard errors } \\
\text { ar dummies. } \\
\text { at the mome } \\
\text { many peopl } \\
\text { ou spend on } \\
\text { e directly be }\end{array}$ & $\begin{array}{l}\text { atheses. } \\
\text { ection } 4 \text {. } \\
\text { ude you } \\
\text { o train i } \\
\text { nture eac } \\
\text { from yo }\end{array}$ & $\begin{array}{l}\text { ecifications } \\
\text { more details } \\
\text { if applicable } \\
\text { last } 12 \text { mor } \\
\text { ek?; (6) Inc }\end{array}$ & $\begin{array}{l}\text { clude cont } \\
\text { urvey que } \\
\text { ull-time); } \\
\text { s?; (4) Do } \\
\text { ing the Av }\end{array}$ & $\begin{array}{l}\text { for gender, } \\
\text { ns for each } \\
\text { How many } \\
\text { u draw any } \\
\text { d, what was }\end{array}$ \\
\hline
\end{tabular}




\title{
Online Appendix for:
}

“How Do Nascent Social Entrepreneurs Respond to Rewards?

A Field Experiment on Motivations in a Grant Competition"

Ina Ganguli ${ }^{1,4}$, Marieke Huysentruyt ${ }^{2,4}$, and Chloé Le Coq ${ }^{3,4}$

\author{
${ }^{1}$ University of Massachusetts Amherst \\ ${ }^{2}$ HEC Paris \\ ${ }^{3}$ University of Paris II Panthéon-Assas (CRED) \\ ${ }^{4}$ Stockholm School of Economics (SITE)
}




\section{APPENDIX}

Figure A1. Detailed Visual Representation of our Research Design
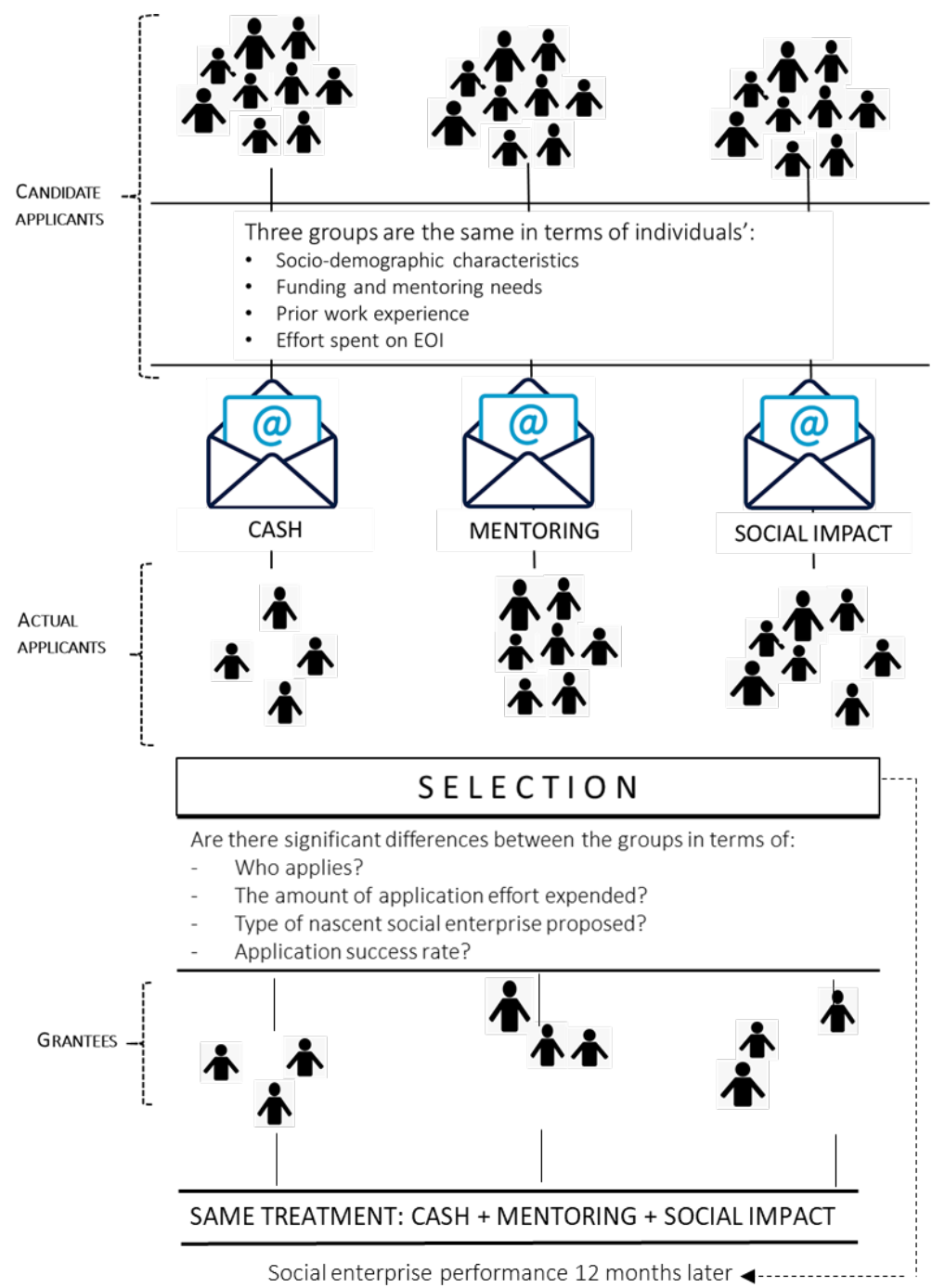
Table A1. Interrater Reliability Scores of Measures of Prior Experience and Perceived Challenges

\begin{tabular}{|c|c|c|c|c|c|c|c|}
\hline & & $(1)$ & $(2)$ & (3) & (4) & $(5)$ & $(6)$ \\
\hline Variable name & Variable description & Agreement & $\begin{array}{c}\text { Expected } \\
\text { agreement }\end{array}$ & Kappa & Std. Error & $\mathrm{Z}$ & Prob $>Z$ \\
\hline \multicolumn{8}{|c|}{ Prior Work Experience } \\
\hline Social Sector & $\begin{array}{l}\text { Dummy indicating whether the } \\
\text { applicant has previous work } \\
\text { experience in the social sector }\end{array}$ & $99.15 \%$ & $60.65 \%$ & 0.9783 & 0.0462 & 21.17 & 0.0000 \\
\hline $\begin{array}{l}\text { For-profit } \\
\text { Sector }\end{array}$ & $\begin{array}{l}\text { Dummy indicating whether the } \\
\text { applicant has previous work } \\
\text { experience in the for-profit } \\
\text { sector }\end{array}$ & $99.36 \%$ & $50.12 \%$ & 0.9871 & 0.0462 & 21.36 & 0.0000 \\
\hline \multicolumn{8}{|c|}{ Main Challenges } \\
\hline $\begin{array}{l}\text { Money } \\
\text { Challenge }\end{array}$ & $\begin{array}{l}\text { Dummy indicating whether the } \\
\text { applicant expressed a money- } \\
\text { related challenge }\end{array}$ & $96.44 \%$ & $51.45 \%$ & 0.9266 & 0.0457 & 20.26 & 0.0000 \\
\hline $\begin{array}{l}\text { Support } \\
\text { Challenge }\end{array}$ & $\begin{array}{l}\text { Dummy indicating whether the } \\
\text { applicant expressed a } \\
\text { support/advice-related challenge }\end{array}$ & $97.90 \%$ & $51.11 \%$ & 0.9571 & 0.0458 & 20.90 & 0.0000 \\
\hline $\begin{array}{l}\text { Social Impact } \\
\text { Challenge }\end{array}$ & $\begin{array}{l}\text { Dummy indicating whether the } \\
\text { applicant expressed a social } \\
\text { impact related challenge }\end{array}$ & $98.52 \%$ & $76.10 \%$ & 0.9380 & 0.0460 & 20.38 & 0.0000 \\
\hline
\end{tabular}


Table A2. Treatment Effects on Characteristics of Applicants from EOI ( $N=290)$

\begin{tabular}{|c|c|c|c|c|c|c|}
\hline & \multicolumn{2}{|l|}{ Treatment Group } & & \multicolumn{3}{|l|}{ Differences } \\
\hline & Social & Cash & Support & $(1)-(2)$ & (1) - (3) & $(2)-(3)$ \\
\hline & (1) & (2) & (3) & (4) & (5) & (6) \\
\hline \multirow[t]{2}{*}{ Female } & 0.689 & 0.506 & 0.653 & $0.184^{* *}$ & -0.036 & $0.147^{*}$ \\
\hline & $(0.465)$ & $(0.503)$ & $(0.478)$ & & & \\
\hline \multirow[t]{2}{*}{ Age } & 39.466 & 38.629 & 41.633 & 0.837 & 2.167 & 3.003 \\
\hline & (11.268) & $(12.885)$ & $(11.520)$ & & & \\
\hline \multirow[t]{2}{*}{ London } & 0.233 & 0.236 & 0.224 & -0.003 & -0.009 & -0.011 \\
\hline & $(0.425)$ & $(0.394)$ & $(0.419)$ & & & \\
\hline \multirow[t]{2}{*}{$\mathrm{Nb}$. of Words in EOI } & 173.000 & 175.494 & 177.796 & -2.494 & 4.796 & 2.302 \\
\hline & $(60.179)$ & $(61.185)$ & $(63.708)$ & & & \\
\hline $\mathrm{Nb}$. of Observations & 103 & 89 & 98 & & & \\
\hline
\end{tabular}


Table A3. Treatment Effects on Sector $(\mathrm{N}=\mathbf{2 9 0})$

\begin{tabular}{|c|c|c|c|c|c|c|c|c|c|c|c|c|}
\hline & $\begin{array}{c}\text { Agriculture } \\
(1) \\
\end{array}$ & $\begin{array}{c}\text { Culture } \\
\text { (2) }\end{array}$ & $\begin{array}{c}\text { Education } \\
(3) \\
\end{array}$ & $\begin{array}{c}\text { Energy } \\
(4)\end{array}$ & $\begin{array}{c}\text { Environ } \\
\text { ment } \\
(5)\end{array}$ & $\begin{array}{c}\text { Financial } \\
\text { Legal } \\
(6) \\
\end{array}$ & $\begin{array}{c}\text { Health } \\
(7)\end{array}$ & $\begin{array}{c}\text { Housin } \\
\mathrm{g} \\
(8)\end{array}$ & $\begin{array}{l}\text { ICT } \\
(9) \\
\end{array}$ & $\begin{array}{c}\text { Supply } \\
\text { Chain } \\
(10)\end{array}$ & $\begin{array}{c}\text { Tech } \\
\text { Assist } \\
(11) \\
\end{array}$ & $\begin{array}{c}\text { Tourism } \\
(12) \\
\end{array}$ \\
\hline \multicolumn{13}{|l|}{$\begin{array}{l}\text { A.Pooled Treatment } \\
\text { Groups }\end{array}$} \\
\hline Cash + Support & $\begin{array}{l}-0.008 \\
(0.019)\end{array}$ & $\begin{array}{l}0.029 \\
(0.035)\end{array}$ & $\begin{array}{l}-0.009 \\
(0.042)\end{array}$ & $\begin{array}{l}-0.013 \\
(0.013)\end{array}$ & $\begin{array}{l}0.034 \\
(0.031)\end{array}$ & $\begin{array}{l}0.028 \\
(0.019)\end{array}$ & $\begin{array}{l}-0.009 \\
(0.042)\end{array}$ & $\begin{array}{l}0.028 \\
(0.034)\end{array}$ & $\begin{array}{l}0.026 \\
(0.025)\end{array}$ & $\begin{array}{l}-0.029^{*} \\
(0.014)\end{array}$ & $\begin{array}{l}-0.001 \\
(0.005)\end{array}$ & $\begin{array}{l}0.023 \\
(0.016)\end{array}$ \\
\hline \multirow{2}{*}{\multicolumn{13}{|c|}{ Groups Separated }} \\
\hline & & & & & & & & & & & & \\
\hline Cash & $\begin{array}{l}-0.017 \\
(0.025)\end{array}$ & $\begin{array}{l}0.009 \\
(0.037)\end{array}$ & $\begin{array}{l}-0.007 \\
(0.055)\end{array}$ & $\begin{array}{l}-0.011 \\
(0.012)\end{array}$ & $\begin{array}{l}0.041 \\
(0.046)\end{array}$ & $\begin{array}{l}0.046 \\
(0.030)\end{array}$ & $\begin{array}{l}-0.016 \\
(0.051)\end{array}$ & $\begin{array}{l}0.021 \\
(0.043)\end{array}$ & $\begin{array}{l}0.019 \\
(0.032)\end{array}$ & $\begin{array}{l}-0.032^{*} \\
(0.016)\end{array}$ & $\begin{array}{l}-0.003 \\
(0.006)\end{array}$ & $\begin{array}{l}0.040^{+} \\
(0.022)\end{array}$ \\
\hline Support & $\begin{array}{l}-0.000 \\
(0.021)\end{array}$ & $\begin{array}{l}0.046 \\
(0.043)\end{array}$ & $\begin{array}{l}-0.011 \\
(0.048)\end{array}$ & $\begin{array}{l}-0.014 \\
(0.015)\end{array}$ & $\begin{array}{l}0.028 \\
(0.034)\end{array}$ & $\begin{array}{l}0.013 \\
(0.012)\end{array}$ & $\begin{array}{l}-0.003 \\
(0.051)\end{array}$ & $\begin{array}{l}0.034 \\
(0.042)\end{array}$ & $\begin{array}{l}0.032 \\
(0.027)\end{array}$ & $\begin{array}{l}-0.027^{+} \\
(0.014)\end{array}$ & $\begin{array}{l}0.001 \\
(0.006)\end{array}$ & $\begin{array}{l}0.008 \\
(0.021)\end{array}$ \\
\hline $\mathrm{Nb}$. of Obs. & 290 & 290 & 290 & 290 & 290 & 290 & 290 & 290 & 290 & 290 & 290 & 290 \\
\hline R2 (pooled) & 0.497 & 0.567 & 0.688 & 0.180 & 0.475 & 0.518 & 0.584 & 0.625 & 0.529 & 0.685 & 0.700 & 0.587 \\
\hline Mean of Y (Social) & 0.029 & 0.068 & 0.282 & 0.010 & 0.058 & 0.010 & 0.184 & 0.126 & 0.049 & 0.029 & 0.010 & 0.010 \\
\hline
\end{tabular}

Notes. Dependent variable is a dummy variable based on the full application question "Which sector (or sectors) does your venture operate in?". Applicants could select up to 3 sectors. 
Table A4. Definitions of Text Measures from the dictionary-based text analysis of LIWC and DICTION

\begin{tabular}{|c|c|c|}
\hline Variables & Definition & Example of words \\
\hline \multicolumn{3}{|c|}{$\boldsymbol{L I W C}$ (Pennebaker et al., 2015) } \\
\hline Self (orientation) & 'first-person singular pronoun' & I, me, my, mine, myself \\
\hline Other (orientation) & $\begin{array}{l}\text { 'third-person plural pronouns } \\
\text { singular and plural human words ' }\end{array}$ & $\begin{array}{l}\text { they, their, theirs } \\
\text { adult, baby, boy, girl, women, men, people }\end{array}$ \\
\hline Interaction process & 'engagement and social process words' & $\begin{array}{l}\text { communicating, connecting, helping, sharing, } \\
\text { relations, giving, telling, listening }\end{array}$ \\
\hline Money & 'words related to money' & cash, bill, revenue, sell, trade \\
\hline \multicolumn{3}{|c|}{ DICTION (Hart and Caroll, 2014) } \\
\hline Collectives & $\begin{array}{l}\text { 'singular nouns connoting plurality that } \\
\text { function to decrease specificity (...) included } \\
\text { are social groupings, task groups, and } \\
\text { geographical entities' }\end{array}$ & $\begin{array}{l}\text { crowd, choir, team, humanity, } \\
\text { army, congress, legislature, staff, } \\
\text { county, world, kingdom, republic }\end{array}$ \\
\hline Cooperation & $\begin{array}{l}\text { 'terms designating behavioral interactions } \\
\text { among people that often result in a group } \\
\text { product'. In particular, it includes personal } \\
\text { involvement, self-denial, as well as work and } \\
\text { social interactions }\end{array}$ & $\begin{array}{l}\text { teamwork, sharing, contribute } \\
\text { public-spirited, care-taking, self-sacrifice } \\
\text { unions, schoolmates, partner, comrade }\end{array}$ \\
\hline Exclusion & $\begin{array}{l}\text { 'describing the sources and effects of social } \\
\text { isolation' }\end{array}$ & $\begin{array}{l}\text { displaced, sequestered, outlaws } \\
\text { small-mindedness, loneliness }\end{array}$ \\
\hline Liberation & $\begin{array}{l}\text { 'describing the maximizing of individual } \\
\text { choice and the rejection of social conventions' }\end{array}$ & $\begin{array}{l}\text { autonomous, open-minded, options } \\
\text { unencumbered, radical, released }\end{array}$ \\
\hline
\end{tabular}


Table A5. Regression Results: Treatment Effects on Ex Ante (EOI) Characteristics and Skills/Experience

\begin{tabular}{|c|c|c|c|c|c|c|c|c|}
\hline \multirow{2}{*}{$\begin{array}{l}\text { Dep Var: Submitted A Full } \\
\text { Application }\end{array}$} & \multicolumn{4}{|c|}{ Characteristic } & \multicolumn{3}{|c|}{$\underline{\text { Skills/Experience }}$} & \multirow{2}{*}{$\begin{array}{l}\frac{\text { Level of }}{\text { Benefit }} \\
\text { International/ } \\
\quad \text { National }\end{array}$} \\
\hline & Female & Age & London & $\begin{array}{c}\text { EOI } \\
\text { Words }\end{array}$ & Social & Business & $\begin{array}{c}\text { Social+ } \\
\text { Business }\end{array}$ & \\
\hline & (1) & (2) & (3) & (4) & $(5)$ & (6) & (7) & (8) \\
\hline \multicolumn{9}{|l|}{$\begin{array}{l}\text { A. Pooled Treatment } \\
\text { Groups }\end{array}$} \\
\hline $\begin{array}{l}\text { Characteristic } \mathrm{x} \\
\text { [Cash + Support }]\end{array}$ & $\begin{array}{l}-0.083 \\
(0.117)\end{array}$ & $\begin{array}{l}-0.002 \\
(0.005)\end{array}$ & $\begin{array}{c}0.153 \\
(0.122)\end{array}$ & $\begin{array}{c}0.035 \\
(0.029)\end{array}$ & $\begin{array}{l}-0.015 \\
(0.132)\end{array}$ & $\begin{array}{c}0.018 \\
(0.115)\end{array}$ & $\begin{array}{c}0.314 \\
(0.228)\end{array}$ & $\begin{array}{l}-0.134 \\
(0.108)\end{array}$ \\
\hline Characteristic & $\begin{array}{c}0.089 \\
(0.096)\end{array}$ & $\begin{array}{l}-0.010 \\
(0.010)\end{array}$ & $\begin{array}{c}0.055 \\
(0.095)\end{array}$ & $\begin{array}{l}-0.030 \\
(0.022)\end{array}$ & $\begin{array}{l}0.037 \\
(0.105)\end{array}$ & $\begin{array}{c}0.092 \\
(0.090)\end{array}$ & $\begin{array}{l}-0.083 \\
(0.194)\end{array}$ & $\begin{array}{c}0.100 \\
(0.088)\end{array}$ \\
\hline Cash + Support & $\begin{array}{l}-0.043 \\
(0.094)\end{array}$ & $\begin{array}{l}-0.012 \\
(0.194)\end{array}$ & $\begin{array}{c}0.037 \\
(0.137) \\
\end{array}$ & $\begin{array}{l}-0.184 \\
(0.161)\end{array}$ & $\begin{array}{l}-0.081 \\
(0.112)\end{array}$ & $\begin{array}{l}-0.105 \\
(0.089) \\
\end{array}$ & $\begin{array}{l}-0.384^{+} \\
(0.218) \\
\end{array}$ & $\begin{array}{l}-0.042 \\
(0.068)\end{array}$ \\
\hline \multicolumn{9}{|l|}{$\begin{array}{l}\text { B. Treatment Groups } \\
\text { Separated }\end{array}$} \\
\hline Characteristic x Cash & $\begin{array}{l}-0.171 \\
(0.135)\end{array}$ & $\begin{array}{l}-0.005 \\
(0.006)\end{array}$ & $\begin{array}{c}0.219 \\
(0.147)\end{array}$ & $\begin{array}{c}0.000 \\
(0.001)\end{array}$ & $\begin{array}{c}0.047 \\
(0.157)\end{array}$ & $\begin{array}{c}0.078 \\
(0.133)\end{array}$ & $\begin{array}{c}0.236 \\
(0.251)\end{array}$ & $\begin{array}{c}-0.056 \\
(0.128)\end{array}$ \\
\hline Characteristic x Support & $\begin{array}{l}-0.006 \\
(0.134)\end{array}$ & $\begin{array}{l}-0.001 \\
(0.006)\end{array}$ & $\begin{array}{c}0.076 \\
(0.135)\end{array}$ & $\begin{array}{c}0.001 \\
(0.001)\end{array}$ & $\begin{array}{l}-0.092 \\
(0.145)\end{array}$ & $\begin{array}{l}-0.070 \\
(0.136)\end{array}$ & $\begin{array}{c}0.396 \\
(0.274)\end{array}$ & $\begin{array}{l}-0.210 \\
(0.129)\end{array}$ \\
\hline Characteristic & $\begin{array}{c}0.086 \\
(0.097)\end{array}$ & $\begin{array}{c}-0.012 \\
(0.010)\end{array}$ & $\begin{array}{c}0.056 \\
(0.095)\end{array}$ & $\begin{array}{c}0.001 \\
(0.001)\end{array}$ & $\begin{array}{c}0.036 \\
(0.105)\end{array}$ & $\begin{array}{c}0.094 \\
(0.090)\end{array}$ & $\begin{array}{c}-0.078 \\
(0.194)\end{array}$ & $\begin{array}{c}0.098 \\
(0.088)\end{array}$ \\
\hline Cash & $\begin{array}{l}-0.046 \\
(0.105)\end{array}$ & $\begin{array}{c}0.035 \\
(0.224)\end{array}$ & $\begin{array}{l}-0.183^{* *} \\
(0.071)\end{array}$ & $\begin{array}{l}-0.221 \\
(0.194)\end{array}$ & $\begin{array}{l}-0.175 \\
(0.133)\end{array}$ & $\begin{array}{c}-0.179^{+} \\
(0.100)\end{array}$ & $\begin{array}{l}-0.355 \\
(0.239)\end{array}$ & $\begin{array}{l}-0.124 \\
(0.080)\end{array}$ \\
\hline Support & $\begin{array}{l}-0.032 \\
(0.108)\end{array}$ & $\begin{array}{c}-0.018 \\
(0.228)\end{array}$ & $\begin{array}{l}-0.055 \\
(0.072) \\
\end{array}$ & $\begin{array}{l}-0.133 \\
(0.180)\end{array}$ & $\begin{array}{c}0.030 \\
(0.125)\end{array}$ & $\begin{array}{l}-0.004 \\
(0.107)\end{array}$ & $\begin{array}{l}-0.415 \\
(0.264)\end{array}$ & $\begin{array}{c}0.039 \\
(0.076)\end{array}$ \\
\hline $\mathrm{Nb}$. of Observations & 431 & 431 & 431 & 431 & 406 & 406 & 406 & 431 \\
\hline $\begin{array}{l}\text { Notes. Social treatment group } 0 \\
\text { London location, list and time ce } \\
\text { measure of the individual's den } \\
\text { number of words in the text fie } \\
\text { individual "What skills and exp } \\
\text { from the following EOI question } \\
{ }^{* *} p<0.01\end{array}$ & $\begin{array}{l}\text { ted. Esti } \\
\text { ols (dum } \\
\text { raphics } \\
\text { ‘Explain } \\
\text { ence mal } \\
\text { Is your v }\end{array}$ & $\begin{array}{l}\mathrm{n} \text { is by } \\
\text { for week } \\
\text { lls/exper } \\
\text { venture } \\
\text { the rigl } \\
\text { for loce }\end{array}$ & $\begin{array}{l}\text { ith robu } \\
\text { EOI ap } \\
\text { from the } \\
\text { hat is ur } \\
\text { on to en }\end{array}$ & $\begin{array}{l}\text { ndard e } \\
\text { ion and } \\
\text { as foll } \\
\text { about } i \\
\text { his ven }\end{array}$ & $\begin{array}{l}\text { parenth } \\
\text { s for th } \\
\text { umns } 1 \\
\text { EOI; } \\
\text { accessf }\end{array}$ & $\begin{array}{l}\text { specifica } \\
\text { deadline } \\
\text { sed on se } \\
5-7 \text { are ch } \\
\text { Column } \\
\text { ection } 4.1\end{array}$ & $\begin{array}{l}\text { lude cont } \\
\text { "). Chara } \\
\text { ed measu } \\
m \text { an EOI } \\
\text { d as Inter } \\
\text { e details. }\end{array}$ & $\begin{array}{l}\text { or female, age, } \\
\text { tic is an ex ante } \\
\text { column } 4 \text { is the } \\
\text { tion asking the } \\
\text { nal or National } \\
.10,{ }^{*} p<0.05 \text {, }\end{array}$ \\
\hline
\end{tabular}




\section{A6. Example of an email sent to an applicant who had submitted one EOI and was part of the Cash treatment}

From: $X X X$
Sent: $X X X$

To: 'X@hotmail.co.uk'

Subject: XXX Funding Application \#

Importance: High

Dear X,

Following a review of your expression of interest by an Award Manager I am pleased to confirm that you have been invited to apply for a grant.

Please find attached the full application form for completion and guidance notes to assist you. The initial information you provided in your expression of interest can form part of your application, which must be fully completed before you return it to us.

\section{[Additional text for the Cash treatment]}

[If your application is successful, this award will provide you with various resources, notably a cash award of up to $£ 5,000$

We provide these financial resources that can help you take the next step in your journey\}

Due to the exceptionally high volume of interest in our Awards, we have three application windows per year. If your application is accepted, we will invite you to pitch to the next Award panel which is in September 20XX. You will need to take into consideration the following key dates:

You can submit your application up You will be notified if you have been until noon:
If your application is accepted, you will be invited to pitch at an Award panel between:
You will be notified of our decision If you are Awarded, your firs during week commencing: meeting will be on:

$1^{\text {st }}$ September 20XX

$12^{\text {th }}$ September $20 X X$

$22^{\text {nd }}$ September $-3^{\text {rd }}$ October 20XX

$27^{\text {th }}$ October 20XX

$6^{\text {th }}$ November 20XX

Upon receipt, we will review your application and an Award Manager may contact you to discuss your venture in more detail. Please bear in mind that this is a competitive process and if at any stage of the process we decide you are not eligible for an XXX Award you will be informed. If you do not submit your application within the specified timeframe you will need to restart the process by submitting a new expression of interest.

To submit your application:

If you would like any pre-application support, please ensure you submit your application by noon $1^{\text {st }}$ September $20 X X$.

Please email us your completed application to xxx

Please do not submit your application form in PDF format.

Don't forget to check your Junk Email inbox, in case any responses are diverted into there.

If you have any questions please do not hesitate to contact me. 
Table A7. Rejection Reasons by Treatment group

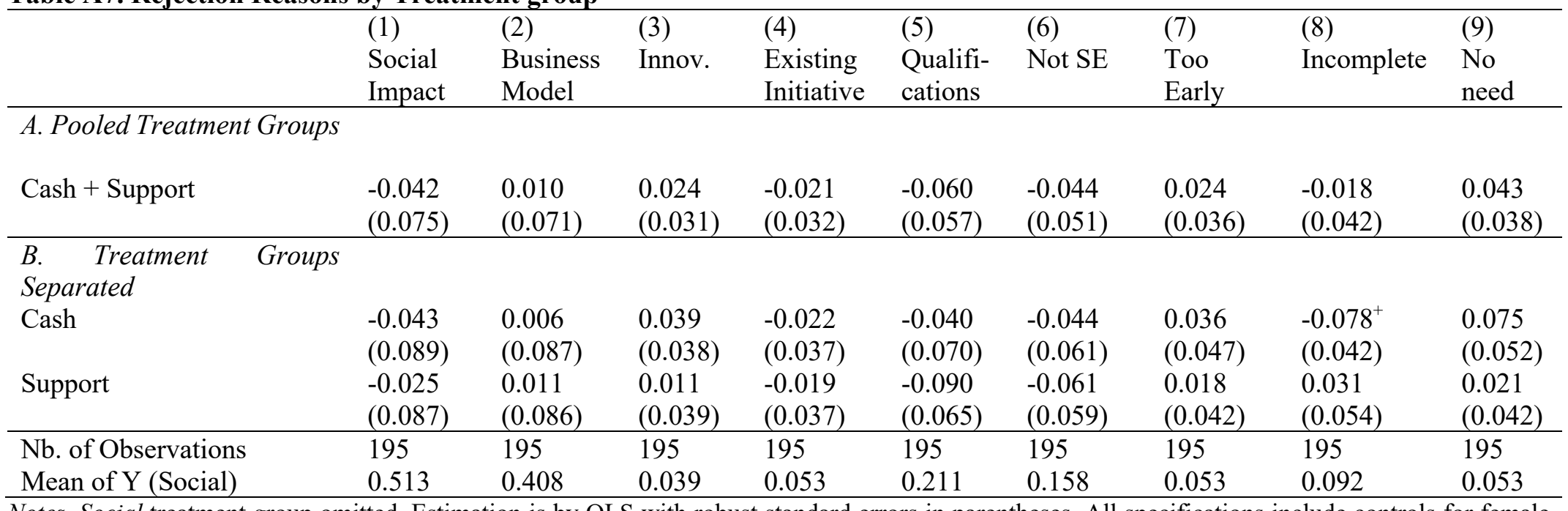

Notes. Social treatment group omitted. Estimation is by OLS with robust standard errors in parentheses. All specifications include controls for female, age, London location, and year dummies. See Section 4.1 for more details. The rejection reasons include (1) Social impact (e.g., 'limited social impact', 'lack of direct social impact', 'weak social aims'); (2) Business model (e.g., 'lacks in sustainability', 'little evidence to support the financial viability', or 'sustainability model unclear'); (3) Innovativeness (e.g., 'not innovative', 'replication'); (4) Fit with existing initiatives; (5) Qualifications of the applicant;

(6) Not a nascent social enterprise (e.g., 'existing venture'); (7) Too early for support; (8) Incomplete application ('application form not filled in properly');

(9) No need for support (e.g., 'the applicant is well supported financially and in terms of mentoring') 
Table A8. Treatment Effects on Additional Post-Grant Outcomes

\begin{tabular}{|c|c|c|c|c|c|c|c|}
\hline & (1) & (2) & (3) & (4) & (5) & (6) & (7) \\
\hline \multicolumn{8}{|c|}{ A. Pooled Treatment Groups } \\
\hline Cash + Support & $\begin{array}{l}-0.022 \\
(0.111)\end{array}$ & $\begin{array}{l}0.135 \\
(0.140)\end{array}$ & $\begin{array}{l}0.217 \\
(0.142)\end{array}$ & $\begin{array}{l}-0.109 \\
(0.140)\end{array}$ & $\begin{array}{l}0.061 \\
(0.141)\end{array}$ & $\begin{array}{l}0.034 \\
(0.118)\end{array}$ & $\begin{array}{l}0.316 \\
(0.559)\end{array}$ \\
\hline \multicolumn{8}{|l|}{ Separated } \\
\hline Cash & $\begin{array}{l}-0.120 \\
(0.147)\end{array}$ & $\begin{array}{l}0.069 \\
(0.164)\end{array}$ & $\begin{array}{l}0.247 \\
(0.164)\end{array}$ & $\begin{array}{l}-0.165 \\
(0.164)\end{array}$ & $\begin{array}{l}0.001 \\
(0.168)\end{array}$ & $\begin{array}{l}-0.036 \\
(0.151)\end{array}$ & $\begin{array}{l}-0.004 \\
(0.707)\end{array}$ \\
\hline Support & $\begin{array}{l}0.049 \\
(0.113)\end{array}$ & $\begin{array}{l}0.183 \\
(0.155)\end{array}$ & $\begin{array}{l}0.196 \\
(0.157)\end{array}$ & $\begin{array}{l}-0.069 \\
(0.157)\end{array}$ & $\begin{array}{l}0.105 \\
(0.153)\end{array}$ & $\begin{array}{l}0.084 \\
(0.122)\end{array}$ & $\begin{array}{l}0.548 \\
(0.598)\end{array}$ \\
\hline Nb. of Observations & 64 & 64 & 64 & 64 & 64 & 64 & 64 \\
\hline Mean of Y (Social) & 0.833 & 0.556 & 0.556 & 0.667 & 0.667 & 0.778 & 4.056 \\
\hline
\end{tabular}

Notes: Social treatment group omitted. Estimation is by OLS with robust standard errors in parentheses. All specifications include controls for female, age, London location, sector, and year dummies. See Section 4.1 for more details. The dependent variable is a binary variable for Columns $1-6$, indicating if the respondent answered yes to the question in the post-award survey if, in the past 12 months, their venture did any of the following: (1) Help people connect with others they might not otherwise meet; (2) Help people take positive action as a group; (3) Promote neighbourliness/encourage people to help each other out; (4) Promote trust within or between communities; (5) Give people the opportunity to be involved in decision-making; and (6) Give people access to information. Column 7 is the sum of these variables. 